\title{
Development of a Simple 'Temperature versus Sliding Speed' Wear Map for the Sliding Wear Behaviour of Dissimilar Metallic Interfaces II
}

\author{
I.A. Inman ${ }^{*}$, P.S. Datta ${ }^{\text {a }}$ \\ a Northumbria University, Newcastle upon Tyne, NE1 8ST, UK
}

\begin{abstract}
The variation in behaviour during sliding wear of Nimonic 80A against Stellite 6 (counterface) at $630^{\circ} \mathrm{C}, 690^{\circ} \mathrm{C}$ and $750^{\circ} \mathrm{C}$ and sliding speeds of $0.314,0.405,0.485,0.654$ and $0.905 \mathrm{~m} . \mathrm{s}^{-1}$, was investigated. A 'block-on-cylinder' configuration was used such that debris retention was not encouraged. At $0.314 \mathrm{~m} . \mathrm{s}^{-1}$, mild oxidational wear was observed at all three temperatures, due to transfer and oxidation of Stellite 6-sourced debris to the Nimonic 80A. The wear debris particles generated were compacted and readily sintered together to form wear protective 'glaze' layers, eliminating metallic contact between the two wear surfaces.
\end{abstract}

Increasing sliding speed above $0.314 \mathrm{~m} \cdot \mathrm{s}^{-1}$ progressively changed the preferred debris source from Stellite 6 to Nimonic 80A. Oxide debris generation continued at all other sliding speeds and temperatures, however, debris behaviour was highly dependent on sliding speed / temperature combination. At $630^{\circ} \mathrm{C}$, oxide generation was insufficient to eliminate metallic contact, however, was enough to modify and enhance the wear process (i.e. 'abrasion-assisted-severe-wear'). On raising temperature to $690^{\circ} \mathrm{C}$ or $750^{\circ} \mathrm{C}$, greater oxide generation and residency prevented metallic contact and severe wear. At sliding speeds of 0.405 (690 and $\left.750^{\circ} \mathrm{C}\right)$ and $0.485 \mathrm{~m} \cdot \mathrm{s}^{-1}\left(750^{\circ} \mathrm{C}\right)$ the still relatively low mobility and high residency of this largely Nimonic 80A-sourced debris was sufficient to allow limited sintering and 'glaze' formation and wear levels remained low. Some Stellite 6-sourced Co also improved debris sinterability, most notably at $0.405 \mathrm{~m} . \mathrm{s}^{-1}$.

However, raising sliding speed to $0.485\left(690^{\circ} \mathrm{C}\right), 0.654$ or $0.905 \mathrm{~m} . \mathrm{s}^{-1}$ increased debris mobility and reduced residency. The now completely Nimonic 80A-sourced debris tended not to sinter and form 'glaze', and instead enhanced wear. Interestingly, oxide generation was more pronounced and wear was lower at $0.905 \mathrm{~m} . \mathrm{s}^{-1}$ than at $0.654 \mathrm{~m} . \mathrm{s}^{-1}$, despite the abrasive action and more hostile sliding conditions. The collected data were used to compose a simple temperature-versus-sliding-speed wear map for Nimonic $80 \mathrm{~A}$ wear when slid against Stellite 6.

Keywords: high temperature wear, dissimilar materials, oxide 'glaze' layer, Stellite 6, Nimonic 80A, wear map

\section{Introduction}

The formation of 'glaze' layers during high temperature mild wear occurs when two metallic surfaces (or a metallic verses a suitable ceramic surface) slide relative to one another under certain combinations of key tribological parameters, important amongst which are load, temperature and sliding speed. Comprehensive studies of conditions needed for 'glaze' generation have been carried out within AMRI [1-8] and elsewhere [9-30]; such studies indicate that under favourable conditions (especially at higher temperatures), a combination of elemental transfer, debris generation and oxidation, and where possible sintering can lead to the formation of wear protective, nano-crystalline 'glaze' layers $[1,2,4,5]$. Also, oxide chemistry can greatly affect the debris' sinterability and thus the readiness with which the 'glaze' is formed $[1,5,6]$. 
Lancaster [24], Welsh [25,26], So [27,28] and others [29,30] have shown that various combinations of load, temperature and sliding speed can significantly affect wear behaviour, particularly whether or not a protective 'glaze' can form. Several authors have also constructed wear maps in an attempt to present wear data in an easily understood format, allowing prediction of likely wear mode under specificed sliding conditions. Lim [31,32], Childs [33] and more recently Riahi and Alpas [34], Chen and Alpas [35], Yang et al [36] Grimanelis and Eyre [37, 38] and Elleucha et al [39] constructed wear maps for various sliding systems based on load / pressure and sliding speed. Other wear combinations can also be used and Kato and Hokkirigawa [40] developed an abrasive wear map using 'degree of penetration (of asperities)' and 'shear strength at the contact interface' as key parameters. Adachi et al [41] used 'severity of contact' and 'thermal severity of contact' on studying ceramic wear. However, most wear maps have been constructed using room temperature data with little work on high ambient temperature sliding or utilising dissimilar interfaces.

Within AMRI, study of the Nimonic 80A versus Stellite 6 [1,4,5] and Incoloy MA 956 versus Stellite 6 [6] wear pairs has indicated that sliding speed and temperature can together affect which surface undergoes greater wear and also the wear modes observed in a dissimilar interface sliding system. For both these systems, such data has been collected together to create simple 'temperature versus sliding speed' wear maps $[5,6]$.

However, these wear maps have weaknesses that require resolution to provide a fuller picture of wear and identify with greater accuracy, the boundaries between the various wear types. It is necessary to carry out sliding wear at a greater number of temperatures and sliding speeds, since both these wear maps $[5,6]$ can only define wear mode to within the nearest $60^{\circ} \mathrm{C}$ (the difference between each test temperature) or $\sim 1 / 3 \mathrm{~m} . \mathrm{s}^{-1}$ sliding speed $\left(0.314,0.654\right.$ and $\left.0.905 \mathrm{~m} . \mathrm{s}^{-1}\right)$. For example, for Nimonic 80A versus Stellite 6 [5], the transition from the ready development of Co-based oxide 'glaze' at $0.314 \mathrm{~m} . \mathrm{s}^{-1}$ to abrasive $\mathrm{NiO} / \mathrm{Cr}_{2} \mathrm{O}_{3}$-based loose abrasive oxide at $0.654 \mathrm{~m} . \mathrm{s}^{-1}$ and $0.905 \mathrm{~m} . \mathrm{s}^{-1}$ (690 and $750^{\circ} \mathrm{C}$ ) appears abrupt. The purpose of the current study is to increase the detail of the Nimonic 80A versus Stellite 6 wear map already produced (Fig. 1 [5]) at the three highest temperatures it covers $\left(630^{\circ} \mathrm{C}, 690^{\circ} \mathrm{C}\right.$ and $\left.750^{\circ} \mathrm{C}\right)$ by adding two extra sliding speeds, 0.405 and $0.485 \mathrm{~m} . \mathrm{s}^{-1}$. These extra sliding speeds show that this transition is less abrupt than previously suggested. Also, it is shown that where oxide generation is insufficient to promoted mild wear, its presence may still affect the severe wear process. 


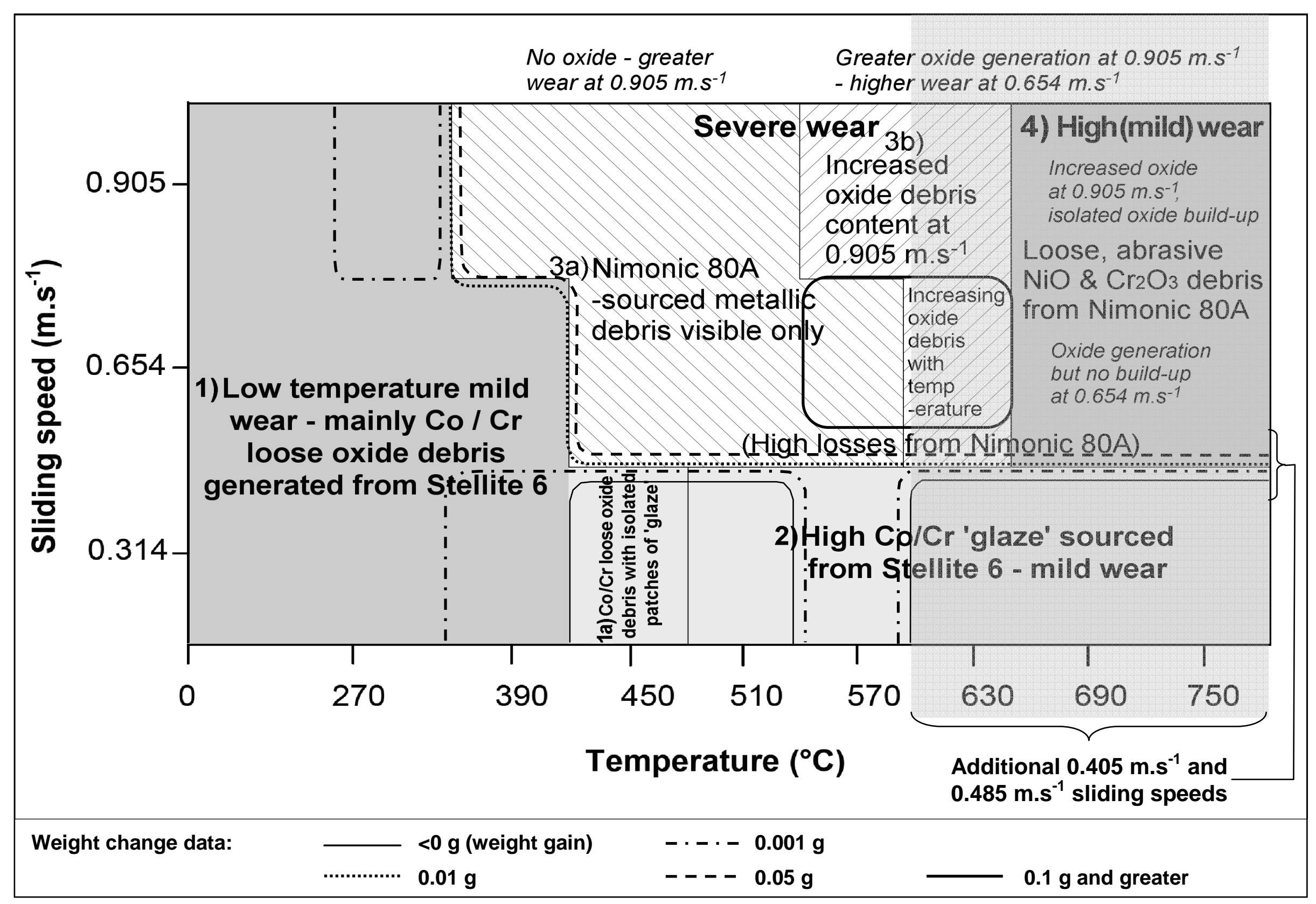

Fig. 1: Wear map for Nimonic 80A versus Stellite 6 (load 7N, sliding distance 4,522 m), with weight loss (contour) data superimposed [5]; the different areas of shading denote the range of conditions over which the various detailed wear conditions were observed

$$
-3-
$$




\section{Experimental}

The alloy compositions used in this study are detailed in Table 1.

\begin{tabular}{rcccccccccc}
\hline & Fe & Ni & Cr & Al & Ti & Mn & W & Co & Si & C \\
\hline Nimonic 80A & 0.7 & 75.8 & 19.4 & 1.4 & 2.5 & - & - & - & 0.1 & 0.08 \\
Stellite 6 & $\begin{array}{c}2.5 \\
\max \end{array}$ & $\begin{array}{c}2.5 \\
\max \end{array}$ & 27 & - & - & 1 & 5 & 60 & 1 & 1 \\
\hline
\end{tabular}

Table 1: Nominal compositions of alloys (at\%)

The tests were carried out using a high temperature 'reciprocating-block-on-rotating-cylinder' wear rig (the blocks forming the samples and the cylinder, the counterface) in air (Fig. 2). The configuration used was such that debris retention was not encouraged. The counterface (Stellite 6), diameter $50 \mathrm{~mm}$ and length 50 $\mathrm{mm}$, was mounted on a shaft rotated by a variable speed electric motor. Samples of Nimonic 80A, $5 \mathrm{~mm}$ x $5 \mathrm{~mm}$ x $45 \mathrm{~mm}$ (acetone-cleaned after polishing to a $1 \mu \mathrm{m}$ surface finish) were held against the counterface (acetone-cleaned after polishing to a 1200 grit finish), using a sample arm in reciprocating motion at 3 cycles per minute and a constant stroke of $12 \mathrm{~mm}$. The tests were carried out at speeds of $0.314,0.405,0.485,0.654$ and $0.905 \mathrm{~m} . \mathrm{s}^{-1}$, under $7 \mathrm{~N}$ load at temperatures of 630,690 and $750^{\circ} \mathrm{C}$. The total sliding distance for all tests was $4,522 \mathrm{~m}$.

A minimum of three tests (one per sample) were conducted for each combination of conditions. Each sample of Nimonic 80A was weighed using a high accuracy Sartorious microbalance before and after sliding, from which a mean weight change for each combination was calculated. The wear of the Stellite 6 counterface was not assessed quantitatively in the current study. The friction data were collected by a Melbourne type TRP-50 torque transducer, connected to the rotating counterface shaft.

The wear surfaces were characterised at a micro-scale level as described previously [1-8]. The microstructures were characterised using scanning electron microscopy (SEM), energy dispersive X-ray (EDX - data in at\%) and X-ray diffraction analysis (XRD). The weight change and characterisation data were used to construct a simple wear map for this combination, based on the nature of wear observed for different combinations of temperature and sliding speed. 


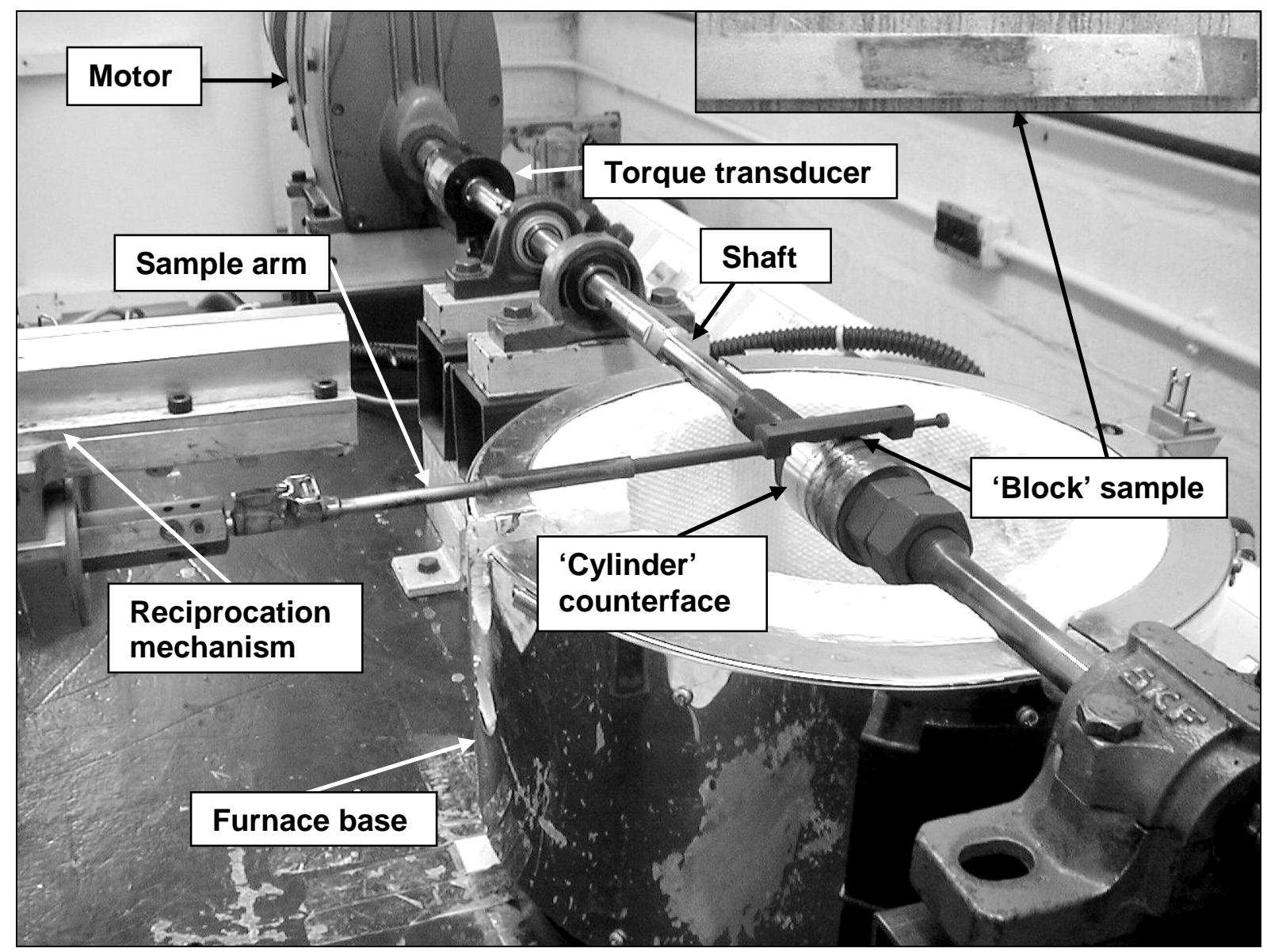

Fig. 2: Reciprocating high temperature block-on-cylinder wear rig plus a Nimonic 80A 'block' sample (shown example with 'glaze' layer formed by sliding at $0.314 \mathrm{~m}_{\mathrm{s}} \mathrm{s}^{-1}$ and $750^{\circ} \mathrm{C}$ against a Stellite 6 counterface or 'cylinder' - load 7N, sliding distance 4,522 m)

\section{Results}

\subsection{Wear at $0.314 \mathrm{~m} . \mathrm{s}^{-1}$}

The Nimonic 80A sample weight change was extremely low (Fig. 3) accompanied by rapid comprehensive 'glaze' layer formation at all three test temperatures (Figs. 4, 5 and 6). This 'glaze' was slightly more fragmented at $630^{\circ} \mathrm{C}$ than at $690^{\circ} \mathrm{C}$ or $750^{\circ} \mathrm{C}$, however, there were slight weight gains in all three cases due to this 'glaze' formation; there was little damage to the underlying Nimonic 80A. Very little accompanying loose debris was observed, with most incorporated into the 'glaze'. Similar 'glaze' layers also formed on the Stellite 6 counterface surface, with only a little accompanying metallic damage.

Point EDX analysis of the 'glaze' covered regions (Figs. 7 to 9) showed high but variable Co levels at between 35 and $55 \%$. At $630^{\circ} \mathrm{C}$ and $690^{\circ} \mathrm{C}$, Ni levels were $<10 \%$ within the 'glaze', although some spot analyses gave between 15 and $18 \%$. Ni levels rose to $\sim 18 \%$ at $750^{\circ} \mathrm{C}$, again with some location-to-location variation. $\mathrm{Cr}$ levels were consistently 30 to 
35\%, regardless of sliding temperature. Most 'glaze' forming oxide was thus Stellite 6-sourced with only a limited Nimonic 80A contribution.

XRD analysis at all temperatures indicated one or more of $\mathrm{Cr}_{2} \mathrm{O}_{3}, \mathrm{CoCr}_{2} \mathrm{O}_{4}$ and $\mathrm{Co}_{3} \mathrm{O}_{4}$ (all phases have near-identical diffraction patterns) within the 'glaze' layers, with the high Co levels favouring $\mathrm{CoCr}_{2} \mathrm{O}_{4}$ and $\mathrm{Co}_{3} \mathrm{O}_{4}$. The Nimonic $80 \mathrm{~A}$ gave a face-centred-cubic Ni-Cr-Fe phase.

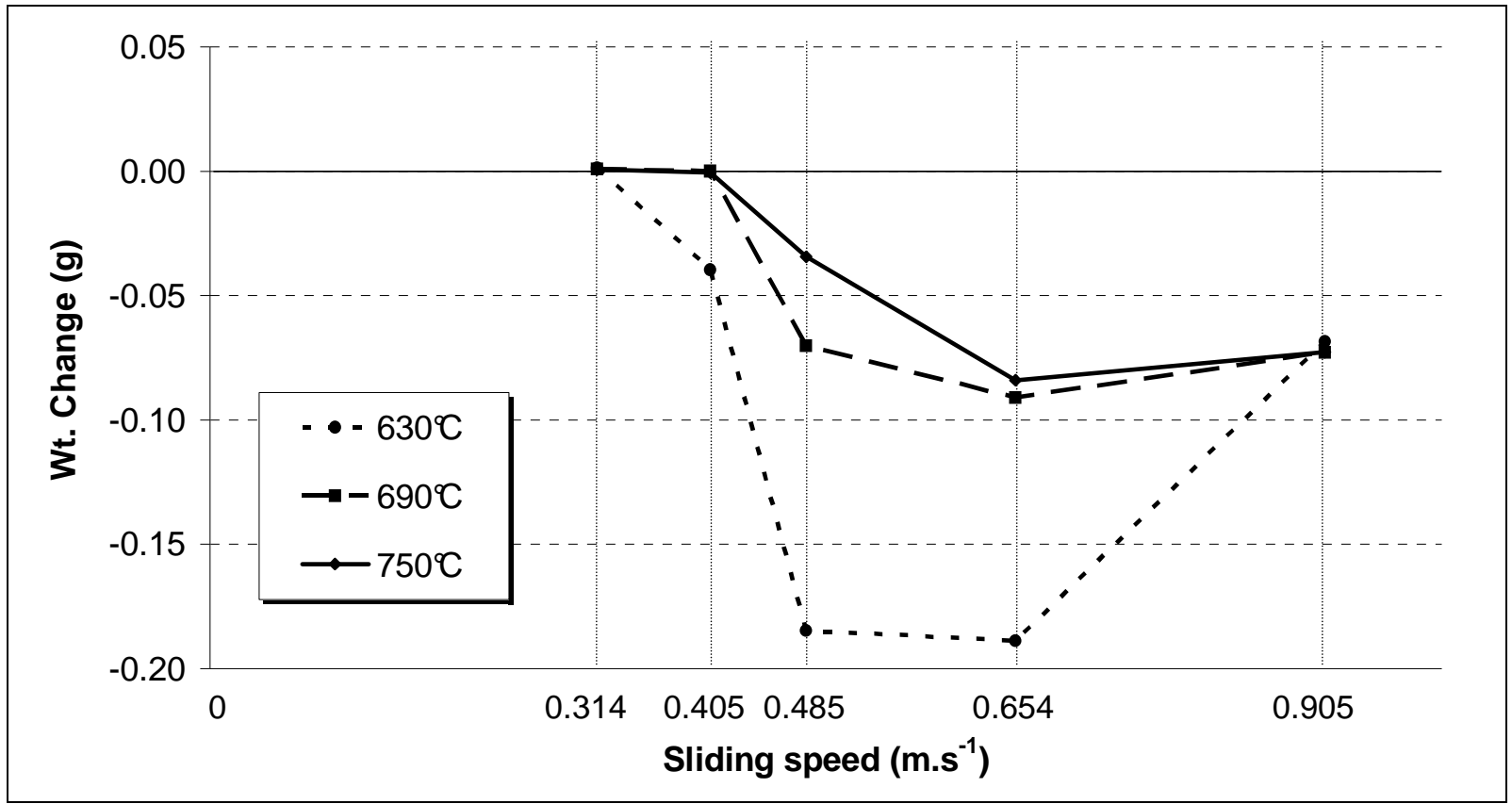

Fig. 3: Weight change versus sliding speed for Nimonic 80A slid against Stellite 6 (load 7N, sliding distance $4,522 \mathrm{~m}$ ) 

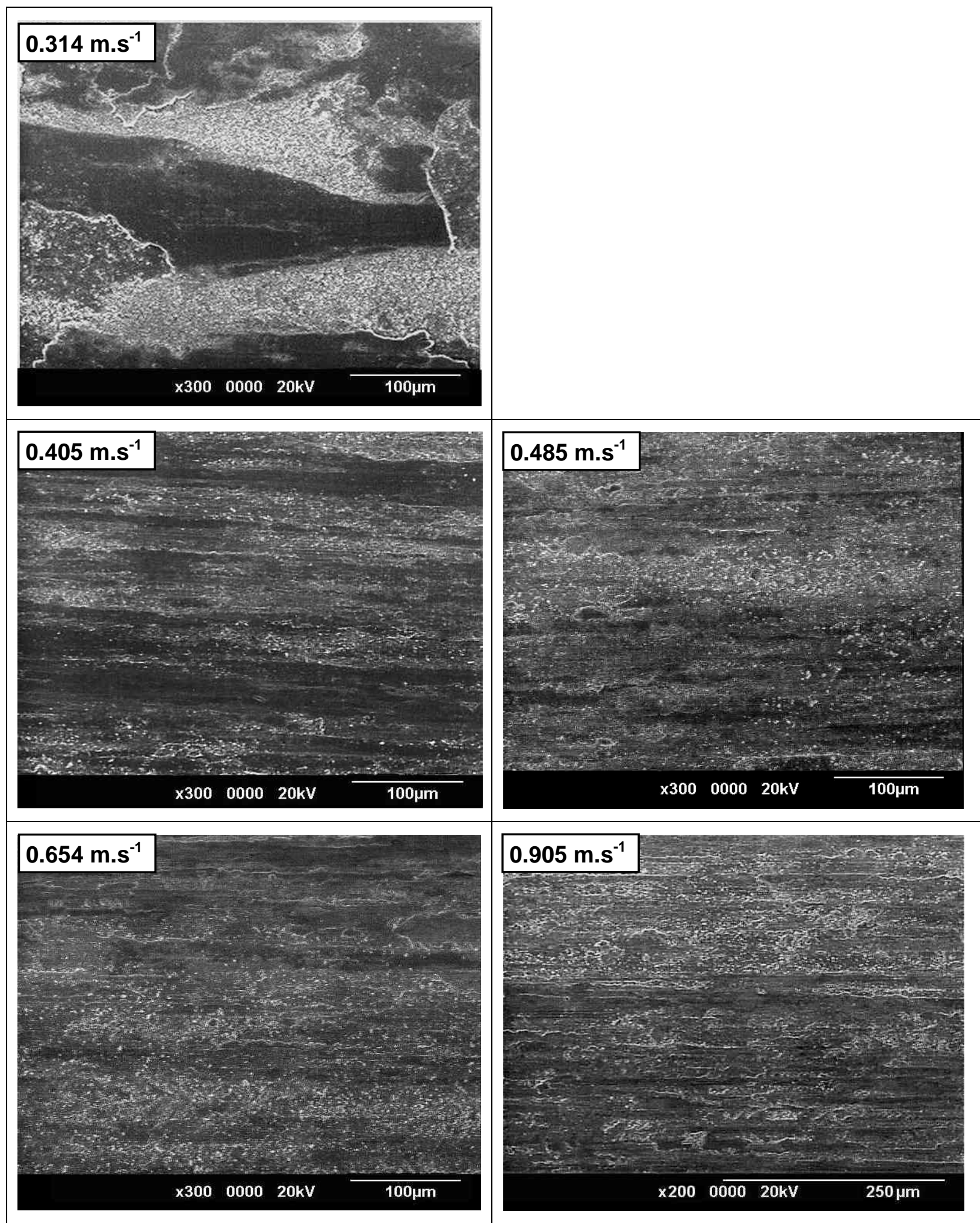

Fig. 4: SEM micrographs of Nimonic $80 \mathrm{~A}$ wear surfaces after sliding at various speeds (load 7N, sliding distance $4,522 \mathrm{~m}$ ) against a Stellite 6 counterface at $630^{\circ} \mathrm{C}$ 


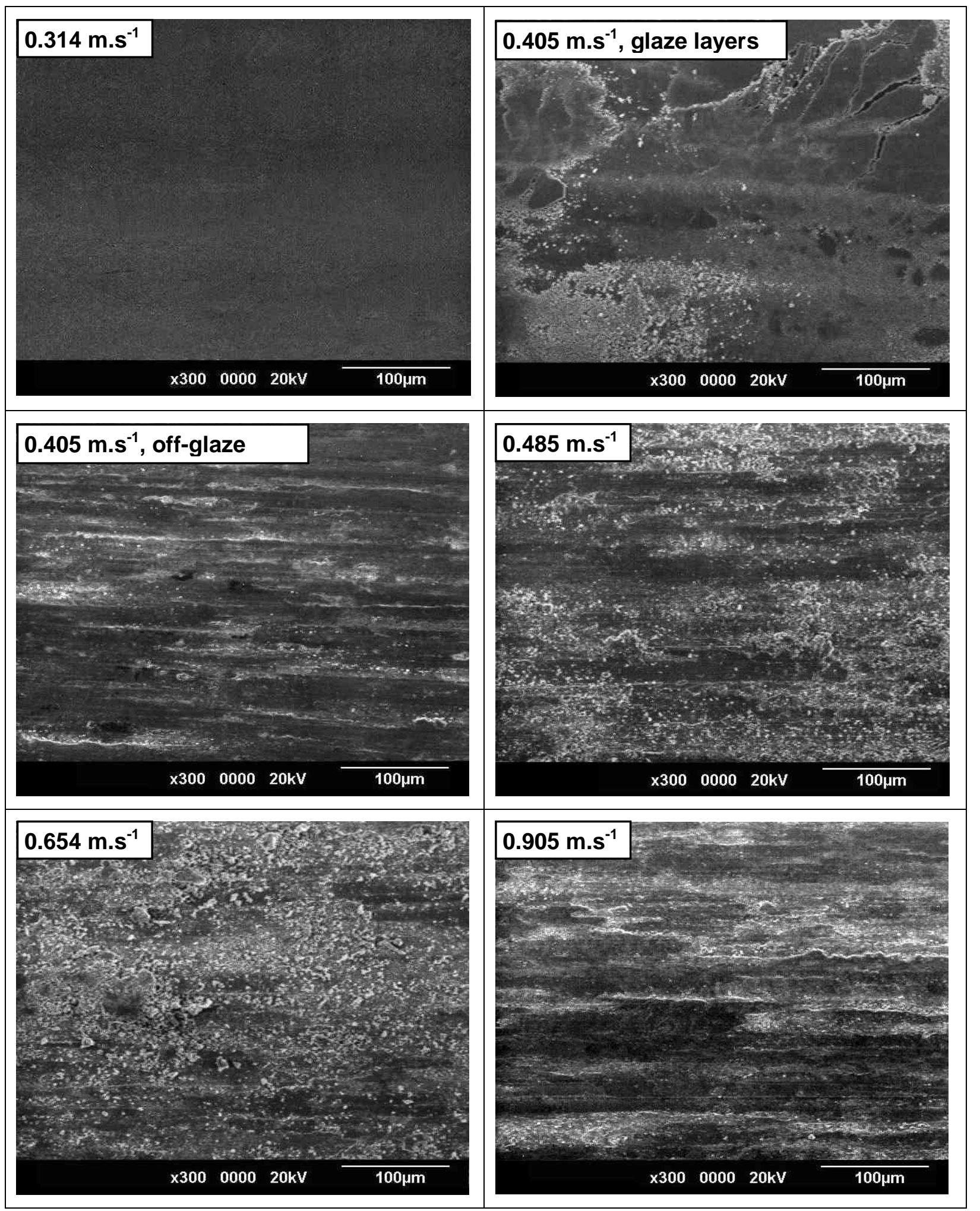

Fig. 5: SEM micrographs of Nimonic $80 \mathrm{~A}$ wear surfaces after sliding at various speeds (load $7 \mathrm{~N}$, sliding distance $4,522 \mathrm{~m}$ ) against a Stellite 6 counterface at $690^{\circ} \mathrm{C}$ 


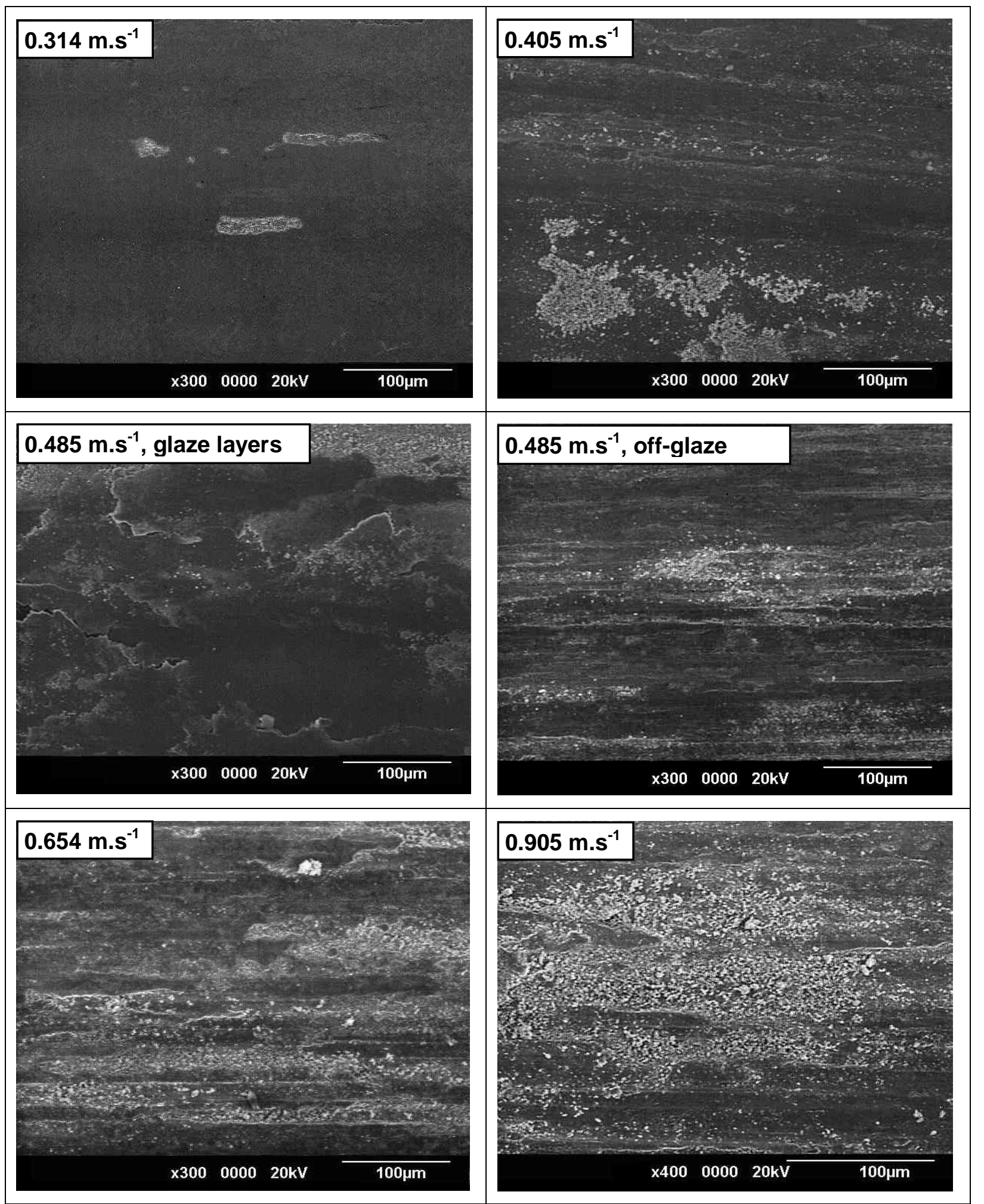

Fig. 6: SEM micrographs of Nimonic $80 \mathrm{~A}$ wear surfaces after sliding at various speeds (load $7 \mathrm{~N}$, sliding distance $4,522 \mathrm{~m}$ ) against a Stellite 6 counterface at $750^{\circ} \mathrm{C}$ 


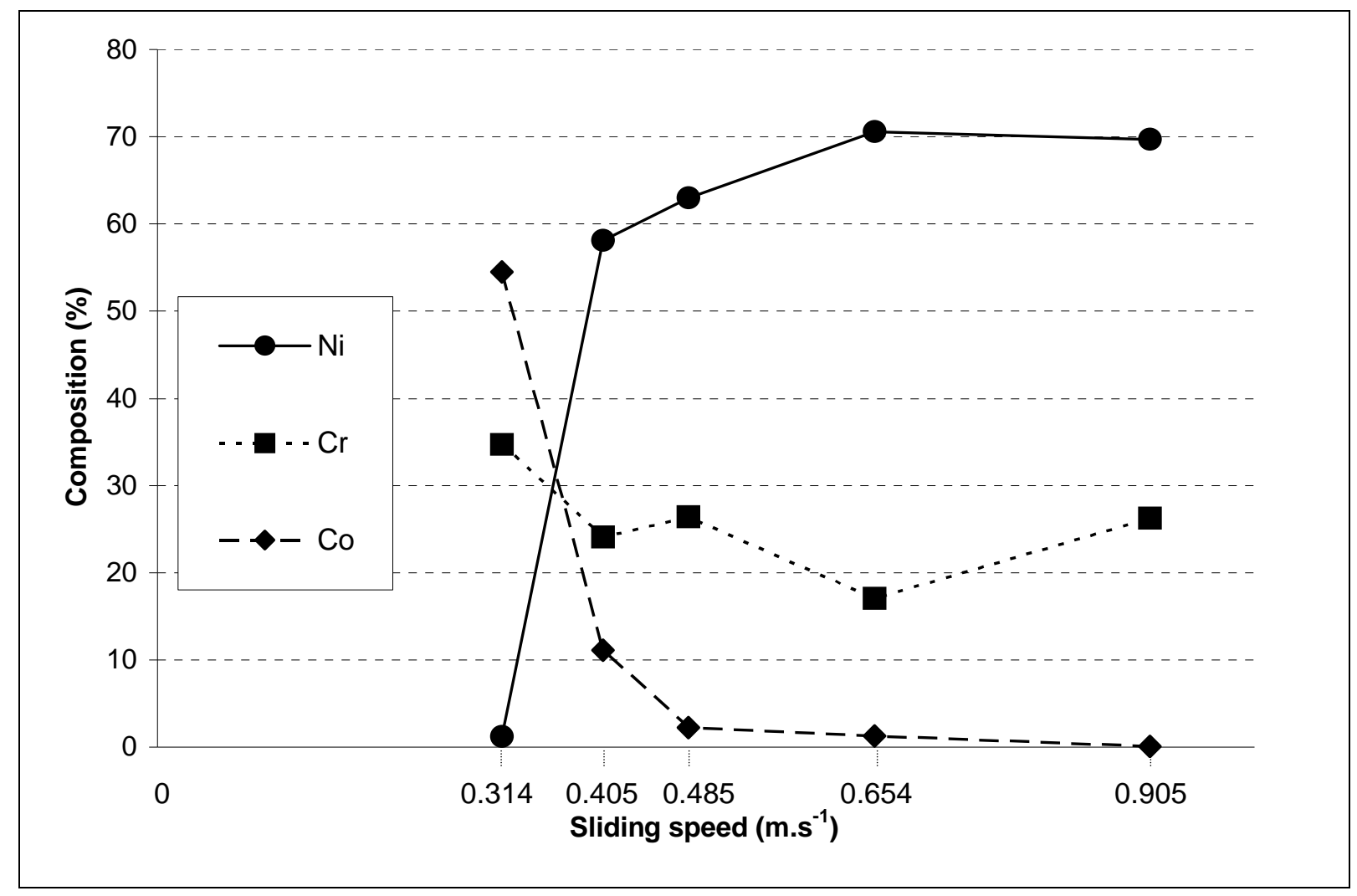

Fig. 7: Compositional variation of oxide debris with sliding speed at $630^{\circ} \mathrm{C}(\mathrm{load}=7 \mathrm{~N}$, sliding distance 4,522)

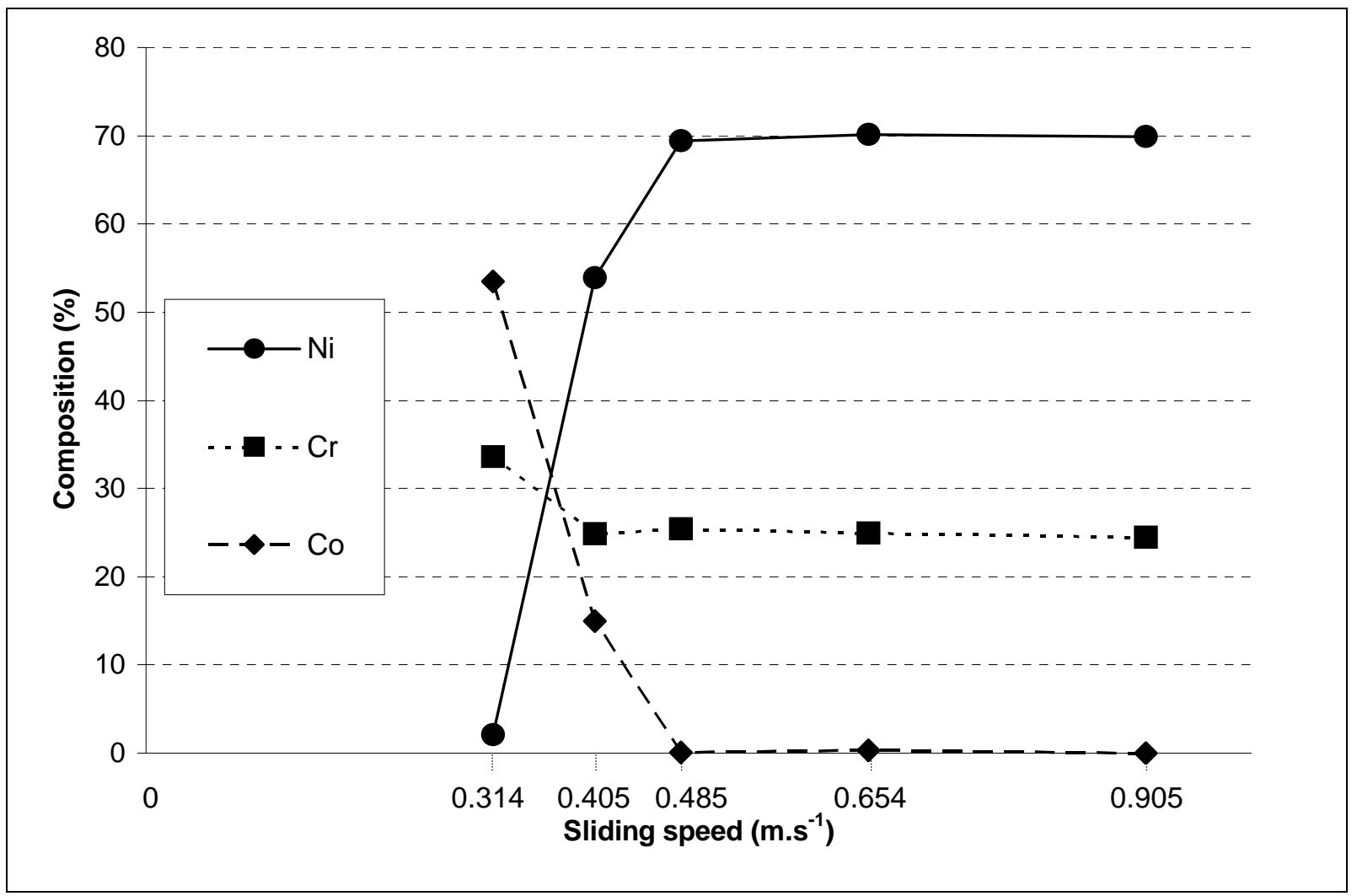

Fig. 8: Compositional variation of oxide debris with sliding speed at $690^{\circ} \mathrm{C}(\mathrm{load}=7 \mathrm{~N}$, sliding distance 4,522) 


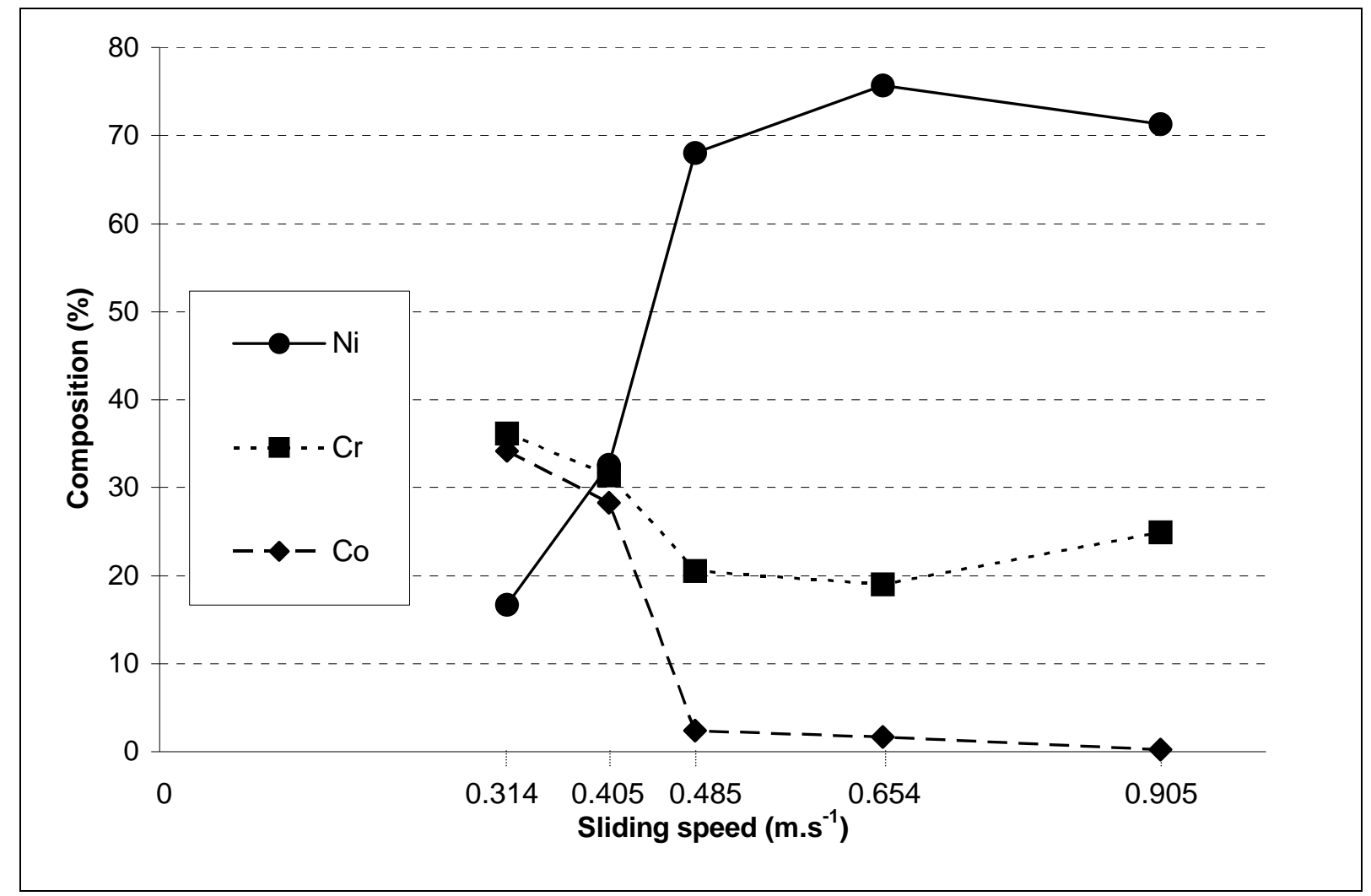

Fig. 9: Compositional variation of oxide debris with sliding speed at $750^{\circ} \mathrm{C}(\operatorname{load}=7 \mathrm{~N}$, sliding distance 4,522)

\subsection{Wear at 0.405 and $0.485{\mathrm{~m} . \mathrm{s}^{-1}}^{-1}$}

At $630^{\circ} \mathrm{C}$, a high weight loss (Fig. 3), severe 'metal-against-metal' adhesive wear regime dominated with metallic debris generation and bright, damaged metallic wear surfaces on both the Nimonic 80A sample (Fig. 4) and Stellite 6 counterface (not shown). These wear surfaces were, however, smoother than severe wear surfaces seen at lower temperatures $[1,4,5]$. Limited quantities of oxide debris were observed, but at insufficient levels to prevent metal-to-metal contact and severe wear. However, the smoother wear surfaces suggest a polishing effect. The debris was readily ejected from the wear interface and there were no signs of 'glaze' layer formation - at best only slight oxide smearing - on either sample or counterface surfaces. There was no apparent bias towards oxide generation at either 0.405 or $0.485 \mathrm{~m} \cdot \mathrm{s}^{-1}$.

Point EDX analysis (Fig. 7) of the limited oxide debris generated at $630^{\circ} \mathrm{C}$ and $0.405 \mathrm{~m} . \mathrm{s}^{-1}$ indicated high levels of Nimonic $80 \mathrm{~A}$-sourced $\mathrm{Ni}$ and $\mathrm{Cr}(\sim 55 \% \mathrm{Ni}, \sim 25 \% \mathrm{Cr})$. There was only a limited amount of Stellite 6-source Co $(\sim 11 \%)$. Co-levels at $0.485 \mathrm{~m} . \mathrm{s}^{-1}$ were even lower $(\sim 2 \%)$, with increased levels of $\mathrm{Ni}(\sim 63 \%)$; Cr-levels (26\%) remained largely unchanged. XRD analysis of the Nimonic 80A wear scar only revealed the Ni-Cr-Fe phase, 
with no oxide phase detected. There was insufficient loose oxide debris for XRD to be viable.

There was a transition to a high temperature oxidational wear regime at $690^{\circ} \mathrm{C}$ and $750^{\circ} \mathrm{C}$ (Figs. 5 and 6), coinciding with decreased sample weight loss (Fig. 3). However, oxide behaviour was different at $0.405 \mathrm{~m} \cdot \mathrm{s}^{-1}$ to that at $0.485 \mathrm{~m} \cdot \mathrm{s}^{-1}$.

At $0.405 \mathrm{~m} . \mathrm{s}^{-1}$, adherent 'glaze' layer formation (Figs. 5 and 6) covered significant parts of the wear scar and wear remained fairly low; the 'glaze' was patchier at $690^{\circ} \mathrm{C}$ than at $750^{\circ} \mathrm{C}$. Where 'glaze' was absent, there was a smooth, worn wear surface across which fine straight grooves ran parallel to the direction of sliding. This grooved pattern indicates that the oxide debris acted as an abrasive. Such exposed 'glaze'-free areas were covered only by a thinly smeared oxide layer. However, despite reduced tendency to 'glaze' formation compared to $0.314 \mathrm{~m} . \mathrm{s}^{-1}$, oxide production was only slightly greater.

At $0.485 \mathrm{~m} . \mathrm{s}^{-1}$, the grooved, worn surface dominated with no 'glaze' layers observed at $690^{\circ} \mathrm{C}$ (Fig. 5); 'glaze' only formed on the edges of the wear scar at $750^{\circ} \mathrm{C}$ and was highly fractured (Fig. 6). This reduced tendency to 'glaze' and compacted oxide layer formation was accompanied by higher levels of wear than at $0.405 \mathrm{~m} . \mathrm{s}^{-1}$ (Fig. 3), though wear at $750^{\circ} \mathrm{C}$ (with trace 'glaze') was lower than at 690C (without 'glaze'). Regardless of whether 'glaze' formation was observed or not, oxide debris production was noticeably higher than at $0.405 \mathrm{~m} \cdot \mathrm{s}^{-1}$.

EDX indicated decreasing $\mathrm{Co}$ and increasing $\mathrm{Ni}$ in the oxide debris with increased sliding speed. At $690^{\circ} \mathrm{C}$ and $0.405 \mathrm{~m} . \mathrm{s}^{-1}$, EDX analysis (Fig. 8) indicated $\sim 15 \% \mathrm{Co}, \sim 59 \% \mathrm{Ni}$ and $25 \% \mathrm{Cr}$ in the loose debris, with similar values for the limited 'glaze' layers on the Nimonic $80 \mathrm{~A}$ surface. Values of $\sim 69 \% \mathrm{Ni}$ and $\sim 27 \% \mathrm{Cr}$ were obtained from the loose oxide debris at $0.485 \mathrm{~m} . \mathrm{s}^{-1}$ in the absence of 'glaze' formation; Co levels were negligible.

Slightly different results were obtained at $750^{\circ} \mathrm{C}$ (Fig. 8). At $0.405 \mathrm{~m} . \mathrm{s}^{-1}$, higher Co $(\sim 28 \%)$ and $\mathrm{Cr}(31 \%)$, and lower Ni levels $(\sim 32.5 \%)$ were recorded from the 'glaze' layers. Higher levels of $\mathrm{Ni}(\sim 68 \%)$ and traces of $\mathrm{Co}(\sim 2.5 \%)$ were recorded from the very limited 'glaze' at $0.485 \mathrm{~m} . \mathrm{s}^{-1}$, with $\mathrm{Cr}$ falling to $\sim 20 \%$. The loose debris gave similar results. 
The dominant phases detected by XRD at 690 and $750^{\circ} \mathrm{C}$ indicated a transition in oxide phase with increasing sliding speed. At $0.405 \mathrm{~m} . \mathrm{s}^{-1}$, the situation was unclear with no clearly identifiable diffraction pattern other than the Nimonic 80A-based Ni-Cr-Fe phase the 'glaze' layer crystallographic phases could not be determined. There was insufficient loose debris at $0.405 \mathrm{~m} . \mathrm{s}^{-1}$ for XRD to be feasible. At $0.485 \mathrm{~m} . \mathrm{s}^{-1}$, a weak signal was obtained for $\mathrm{NiO}$ regardless of whether limited 'glaze' layers were present $\left(750^{\circ} \mathrm{C}\right)$ or there was only oxide smearing on sample surfaces $\left(690^{\circ} \mathrm{C}\right)$. $\mathrm{NiO}$ and $\mathrm{Cr}_{2} \mathrm{O}_{3}$ were detected in the loose debris. No Co-containing phases were detected.

\subsection{Wear at 0.654 and $0.905 \mathrm{~m} . \mathrm{s}^{-1}$}

At $630^{\circ} \mathrm{C}$, the high weight loss (Fig. 3), severe 'metal-against-metal' adhesive wear regime observed at 0.405 and $0.485 \mathrm{~m} . \mathrm{s}^{-1}$ was also noted at 0.654 and $0.905 \mathrm{~m} . \mathrm{s}^{-1}$. High levels of metallic debris and bright, damaged metallic wear surfaces were evident on both the Nimonic 80A sample (Fig. 4) and Stellite 6 counterface (not shown), again smoother than previously observed $[1,4,5]$. Limited oxide generation was again apparent, which was insufficient to prevent metal-to-metal contact and readily ejected from the wear interface. However, a polishing effect was again suggested by the smoother wear surfaces. There was no evidence of 'glaze' or oxide layer development, with only slight oxide smearing on the metallic sample and counterface wear scar surfaces (Fig. 4). The tendency of oxide debris to develop and the amount of oxide smearing was slightly greater at $0.905 \mathrm{~m} . \mathrm{s}^{-1}$ (Fig. 4),

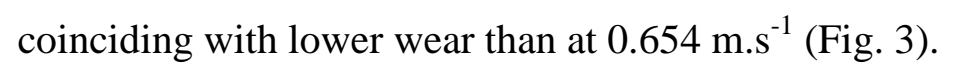

EDX analysis of the limited oxide debris generated at $630^{\circ} \mathrm{C}$ (Fig. 7) indicated high levels of Nimonic 80A-sourced $\mathrm{Ni}$ and $\mathrm{Cr}(\sim 69 \% \mathrm{Ni}, \sim 26 \% \mathrm{Cr})$. XRD analysis of the Nimonic $80 \mathrm{~A}$ only revealed the Ni-Cr-Fe phase, with no oxide phase detected. Insufficient oxide debris was generated for XRD to be viable.

The high temperature oxidational wear transition observed at 0.405 and $0.485 \mathrm{~m} . \mathrm{s}^{-1}$ and temperatures of 690 and $750^{\circ} \mathrm{C}$, also occurred at 0.654 and $0.905 \mathrm{~m} . \mathrm{s}^{-1}$ (Figs. 5 and 6); this transition again coincided with a reduction in weight loss (Fig. 3). However, wear levels at especially 0.654 and also $0.905 \mathrm{~m} . \mathrm{s}^{-1}$ were much higher.

The oxide debris at 0.654 and $0.905 \mathrm{~m} . \mathrm{s}^{-1}$ showed far less tendency to form either compacted oxide or 'glaze' layers on the Nimonic $80 \mathrm{~A}$. At $0.654 \mathrm{~m} . \mathrm{s}^{-1}$, the wear scar at best was covered by a very thinly smeared layer of oxide (Figs. 5 and 6). Continuing high wear levels (Fig. 3) accompanied by fine straight grooves parallel to sliding direction, again 
indicated wear by abrasion. The situation was similar at $0.905 \mathrm{~m} \cdot \mathrm{s}^{-1}$, however, there was a greater tendency for oxide generation. Although no clear cut compacted oxide or 'glaze' layers formed, slight agglomerations of oxide were observed at $0.905 \mathrm{~m} . \mathrm{s}^{-1}$ that were not apparent at $0.654 \mathrm{~m} . \mathrm{s}^{-1}$ (Figs. 5 and 6). Lower wear was observed for $0.905 \mathrm{~m} . \mathrm{s}^{-1}$ at $690^{\circ} \mathrm{C}$ and $750^{\circ} \mathrm{C}$ as it had at $630^{\circ} \mathrm{C}$, although this wear reduction was less marked (Fig. 3 ).

Limited 'glaze' layer development was observed on the Stellite 6 counterface at $690^{\circ} \mathrm{C}$ and $750^{\circ} \mathrm{C}$, accompanied by low levels of counterface wear damage (not shown). This 'glaze' was patchy and easily removed.

EDX of both the fine, thinly smeared oxide layer on the sample surfaces and the loose oxide debris at $690^{\circ} \mathrm{C}$ and $750^{\circ} \mathrm{C}$ (Figs. 8 and 9) gave compositions of $\sim 71 \% \mathrm{Ni}$ and $\sim 24 \%$ $\left(0.654 \mathrm{~m} . \mathrm{s}^{-1}\right) / \sim 25 \% \mathrm{Cr}\left(0.905 \mathrm{~m} . \mathrm{s}^{-1}\right)$, showing they were Nimonic 80A-sourced. The absence of Co indicated no significant transfer from the counterface. The dominant phases indicated by XRD were a face-centred-cubic Ni-Cr-Fe phase from the Nimonic $80 \mathrm{~A}$, and a very weak signal for $\mathrm{NiO}$ from the thinly smeared oxide layer. $\mathrm{NiO}$ and $\mathrm{Cr}_{2} \mathrm{O}_{3}$ were detected in the copious loose debris with no evidence of Co-containing phases.

\subsection{Coefficient of Friction}

Each data set followed a pattern of early unsetlled 'run-in' friction (coefficient of friction could jump as high as between 0.8 and 1.1), followed by a less variable 'steady state'.

There were no clear trends in actual coefficient of friction (not variation), either with temperature or sliding speed (Fig. 10). This may be attributable to the small range of sliding speeds $\left(0.314\right.$ to $\left.0.905 \mathrm{~m} . \mathrm{s}^{-1}\right)$ and temperatures $\left(630,690\right.$ and $\left.750^{\circ} \mathrm{C}\right)$; for example, a clear downward trend in friction was observed previously with temperature [5], when a wider range of temperatures was used (room temperature to $750^{\circ} \mathrm{C}$ ). However, there were changes in frictional variation coinciding with sliding speed, temperature and wear mode.

At $0.314 \mathrm{~m} . \mathrm{s}^{-1}$ (Figs. 11 to 13 ), the 'run-in' period was severely truncated, with an almost instantaneous transition to 'steady state' regardless of temperature; this coincided with the rapid 'glaze' formation observed at this sliding speed. Variation in the steady state was in general low at $\sim 12 \%$.

At $0.405 \mathrm{~m} . \mathrm{s}^{-1}$, higher variation levels of $\sim 20 \%$ were recorded at $630^{\circ} \mathrm{C}$ (Fig. 11), where severe wear dominated and 'glaze' did not form; the transition to steady state although still 
rapid now took up to $300 \mathrm{~m}$. Variation remained at $\sim 20 \%$ at $690^{\circ} \mathrm{C}$ despite 'glaze' formation (Fig. 12); this may indicate repeated formation and break-up of glaze, with spikes in the data being due to break-up events. Due to this variation, it was not possible to clearly determine the beginning of 'steady state' sliding. The situation at $750^{\circ} \mathrm{C}$ (Fig. 13) was very similar to that at $0.314 \mathrm{~m} . \mathrm{s}^{-1}$ with an almost instantaneous transition to 'steady state' and variation levels of $\sim 12 \%$; this signifies rapid, more stable 'glaze' formation with no obvious disruption.

$0.485,0.654$ and $0.905 \mathrm{~m} . \mathrm{s}^{-1}$ showed similar frictional behaviour to each other. Regardless of temperature, the transition to 'steady state' was still fairly rapid but now took up to $300 \mathrm{~m}$. However, variation increased with sliding speed and was also higher at $630^{\circ} \mathrm{C}$ (coinciding with severe wear; Fig. 11) than at $690^{\circ} \mathrm{C}$ and $750^{\circ} \mathrm{C}$ (coinciding with enhanced, abrasive mild wear; Figs. 12 and 13). At $0.485 \mathrm{~m} . \mathrm{s}^{-1}$, variation remained at between $12 \%$ and $15 \%$ regardless of wear mode; the traces of 'glaze' at $750^{\circ} \mathrm{C}$ had no effect. At $0.654 \mathrm{~m} . \mathrm{s}^{-1}$, variation was $\sim 15 \%$ at $630^{\circ} \mathrm{C}$ and $\sim 12 \%$ at $690^{\circ} \mathrm{C}$ and $750^{\circ} \mathrm{C}$. These values increased to $\sim 20 \%$ and $\sim 15 \%$ respectively at $0.905 \mathrm{~m} . \mathrm{s}^{-1}$.

From the observations made, 'run-in' is kept to a minimum under conditions where there is rapid 'glaze' formation. Where protective layers do not form, the presence of oxides during abrasive wear can act to reduce 'steady state' variation compared to that during severe wear (evidence of reduced metallic contact). The one exception to this is at $690^{\circ} \mathrm{C}$ and $0.405 \mathrm{~m} . \mathrm{s}^{-1}$, where the aforementioned high variability may be due to repeated formation, break-up and reformation of 'glaze'.

As with previous studies $[1,4,5]$, variation at 0.654 and $0.905 \mathrm{~m} \cdot \mathrm{s}^{-1}$ is at least partially due to high vibration levels with the 'block-on-cylinder' configuration. Thus caution must be observed when taking into account both the magnitude and variation of the measured data at these sliding speeds. It is likely that true levels of friction may be higher, with reduced contact between sample and counterface and thus lower apparent frictional values due to this vibration. However, it has also been suggested that this reduced friction may be at least partially attributable to increased oxide production at high sliding speed [42] (i.e. at $\left.0.905 \mathrm{~m} \cdot \mathrm{s}^{-1}\right)$. 


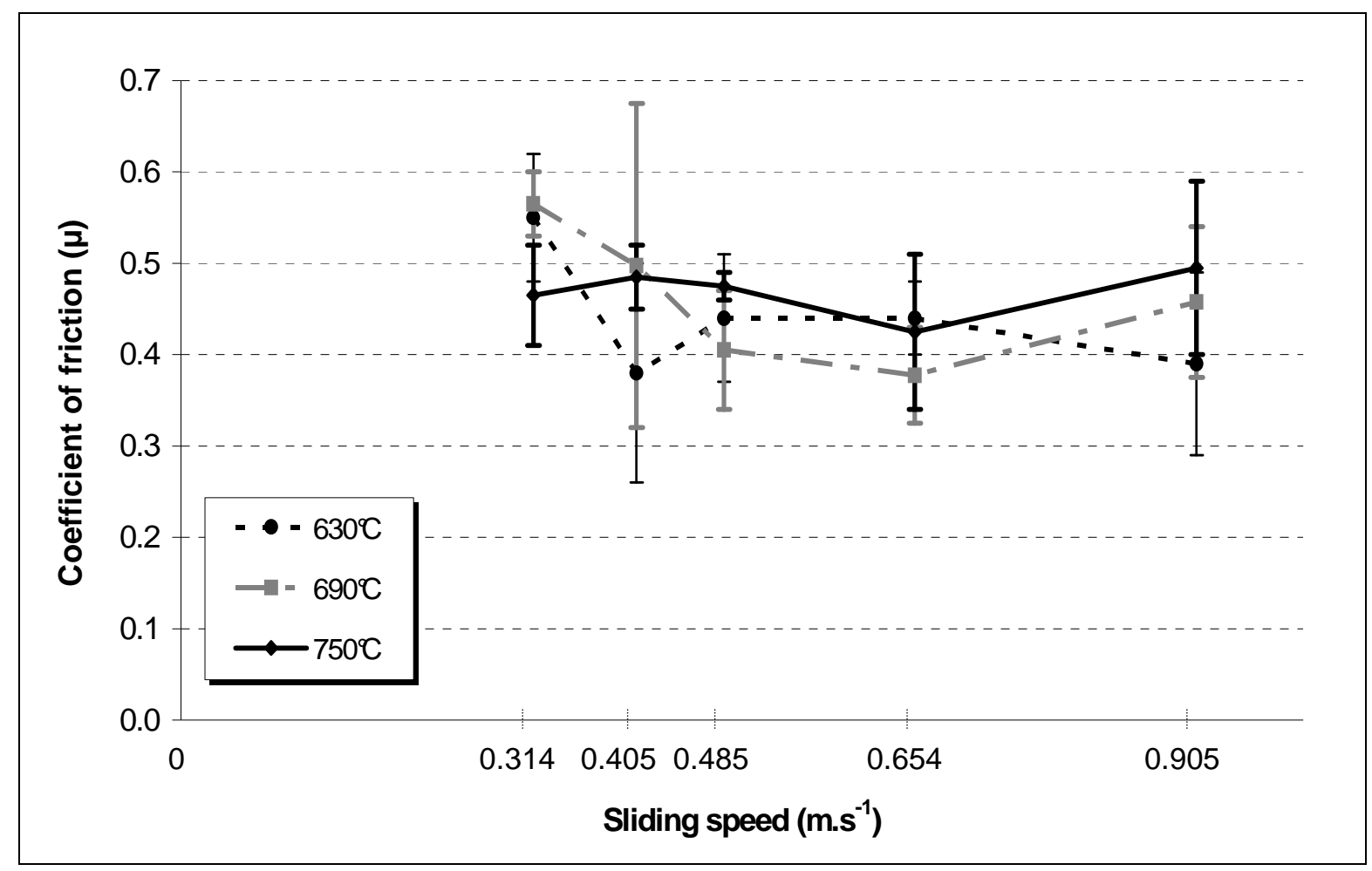

Fig. 10: Variation in 'steady state' friction with sliding speed (load $=7 \mathrm{~N}$, sliding distance $=4,522 \mathrm{~m}$, speed values in ' $\mathrm{m} . \mathrm{s}^{-1}$ ')

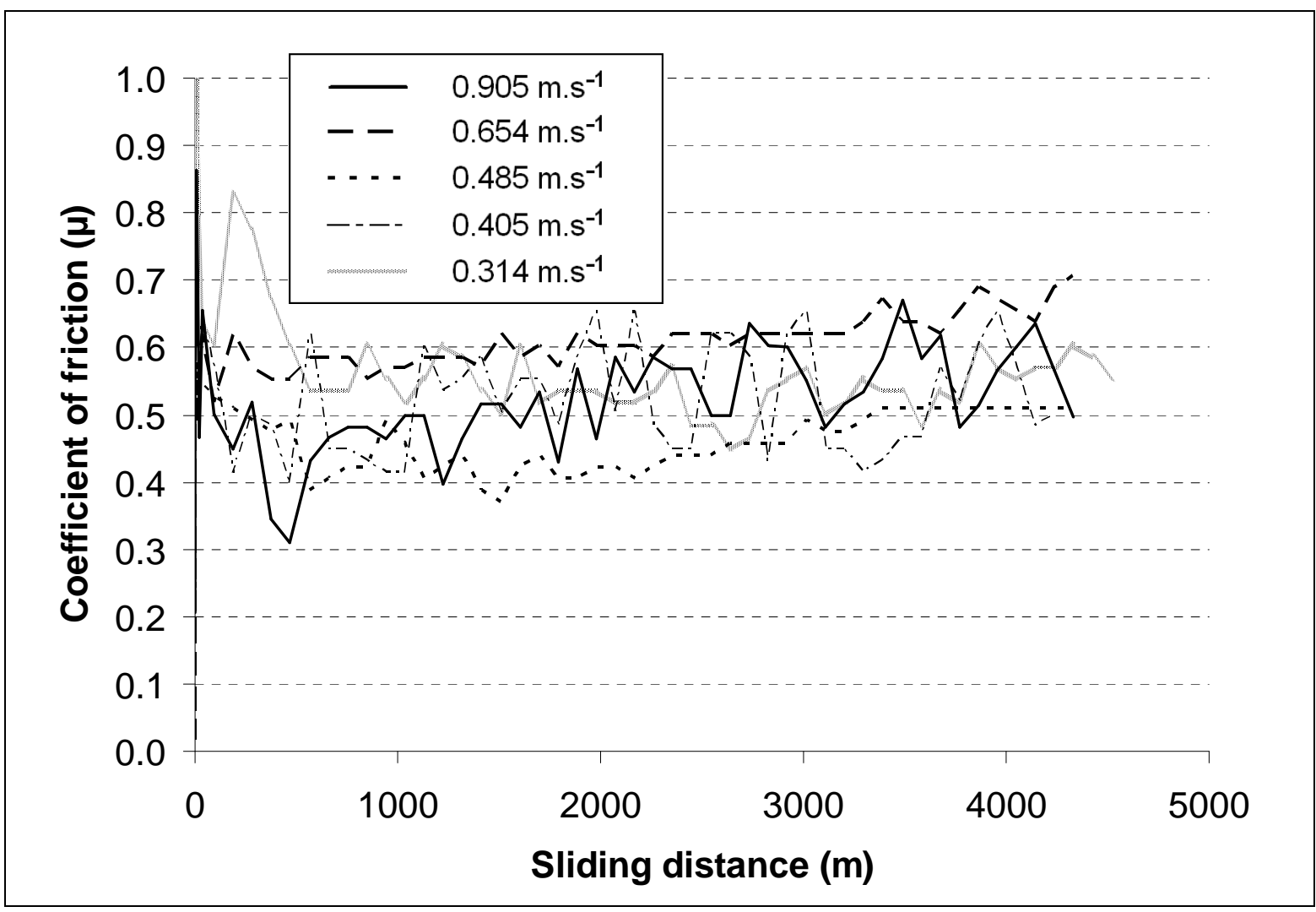

Fig. 11: Coefficient of friction versus sliding speed at $630^{\circ} \mathrm{C} \quad(\operatorname{load}=7 \mathrm{~N}$, sliding distance $=4,522 \mathrm{~m}$ ) 


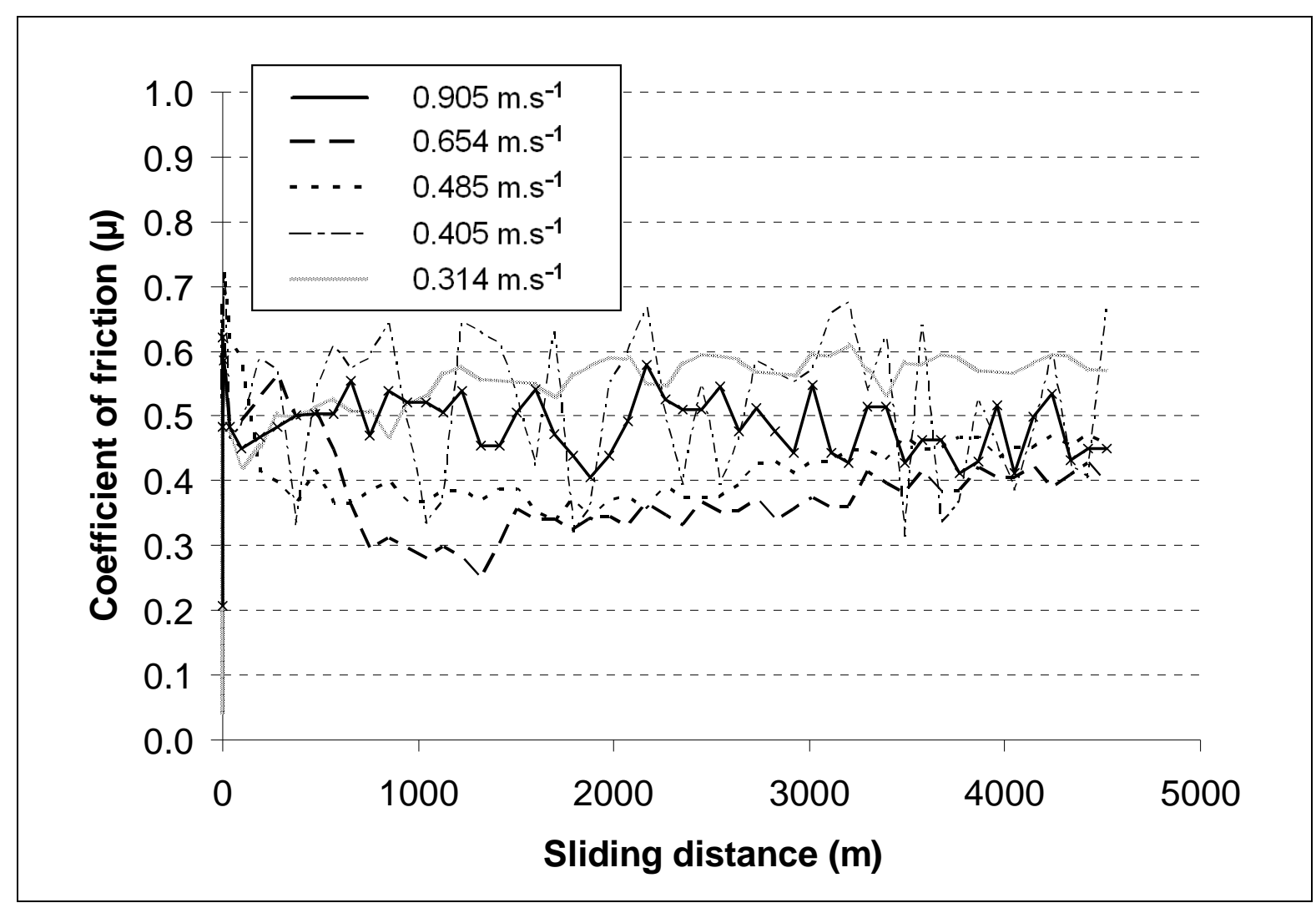

Fig. 12: Coefficient of friction versus sliding speed at $690^{\circ} \mathrm{C} \quad(\mathrm{load}=7 \mathrm{~N}$, sliding distance $=4,522 \mathrm{~m}$ )

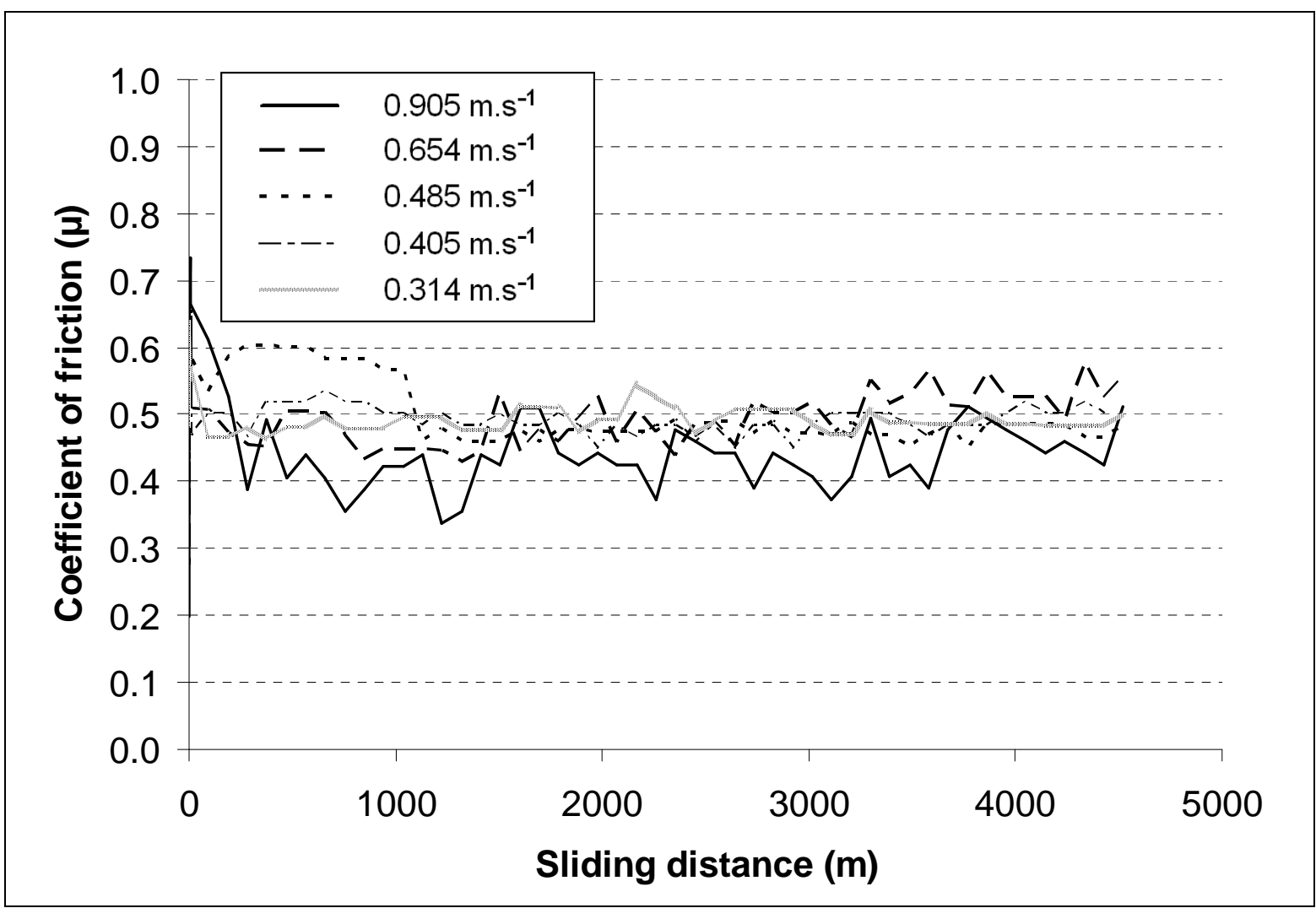

Fig. 13: Coefficient of friction versus sliding speed at $750^{\circ} \mathrm{C}$ (load $=7 \mathrm{~N}$, sliding distance $=4,522 \mathrm{~m}$ ) 


\section{Wear Map for Nimonic 80A versus Stellite 6}

Using the information presented, it is possible to construct the following wear map for Nimonic 80A when slid against Stellite 6 (Fig. 14), describing wear behaviour as a function of sliding speed and temperature. A number of different regions describing types of wear behaviour are shown:

1. Region 1 consisted of high $\mathrm{Co} / \mathrm{Cr}$ oxide 'glaze' sourced from Stellite 6, with low (mild) wear at $0.314 \mathrm{~m} . \mathrm{s}^{-1}$ and all test temperatures.

2. Region 2 was dominated by severe wear and no 'glaze' with mainly metallic and some loose oxide debris at $630^{\circ} \mathrm{C}$ and speeds of 0.405 to $0.905 \mathrm{~m} . \mathrm{s}^{-1}$. Bright, metallic wear surfaces developed with only traces of oxide smearing, however, these wear surfaces were smoother and more polished than expected for severe wear, indicating an abrasive action. Also, there was:

a. increased Co in the oxide debris at $0.405 \mathrm{~m} . \mathrm{s}^{-1}$, and

b. increased oxide debris with some smearing at $0.905 \mathrm{~m} \cdot \mathrm{s}^{-1}$.

3. Region 3 was typified by high Ni- and Cr-based 'glaze' sourced from Nimonic 80A and low (mild) wear at $0.405 \mathrm{~m} \cdot \mathrm{s}^{-1}\left(690^{\circ} \mathrm{C}\right.$ and $\left.750^{\circ} \mathrm{C}\right)$, with significant Co contribution especially at $750^{\circ} \mathrm{C}$. At $690^{\circ} \mathrm{C}$, the 'glaze' was less developed and unstable.

4. Region 4 was predominantly a high (mild) wear regime, with loose, abrasive $\mathrm{NiO} /$ $\mathrm{Cr}_{2} \mathrm{O}_{3}$ debris sourced from the Nimonic 80A. No oxide build-up accompanied this debris at $0.485 \mathrm{~m} \cdot \mathrm{s}^{-1} / 690^{\circ} \mathrm{C}$ and $0.654 \mathrm{~m} \cdot \mathrm{s}^{-1}$ (690 and $750^{\circ} \mathrm{C}$ ), however,:

a. at $0.905 \mathrm{~m} \cdot \mathrm{s}^{-1}$, oxide levels increased with some isolated oxide build-up (though no evolving into 'glaze').

5. Region 5 consisted of some abrasive wear by loose $\mathrm{NiO} / \mathrm{Cr}_{2} \mathrm{O}_{3}$ debris $\left(0.485 \mathrm{~m} . \mathrm{s}^{-1}\right.$ and $750^{\circ} \mathrm{C}$ ). However, very limited $\mathrm{NiO}$ and $\mathrm{Cr}_{2} \mathrm{O}_{3}$ 'glaze' platforms formed around the edges of the abrasion-worn wear scar; with only traces of Co present. 


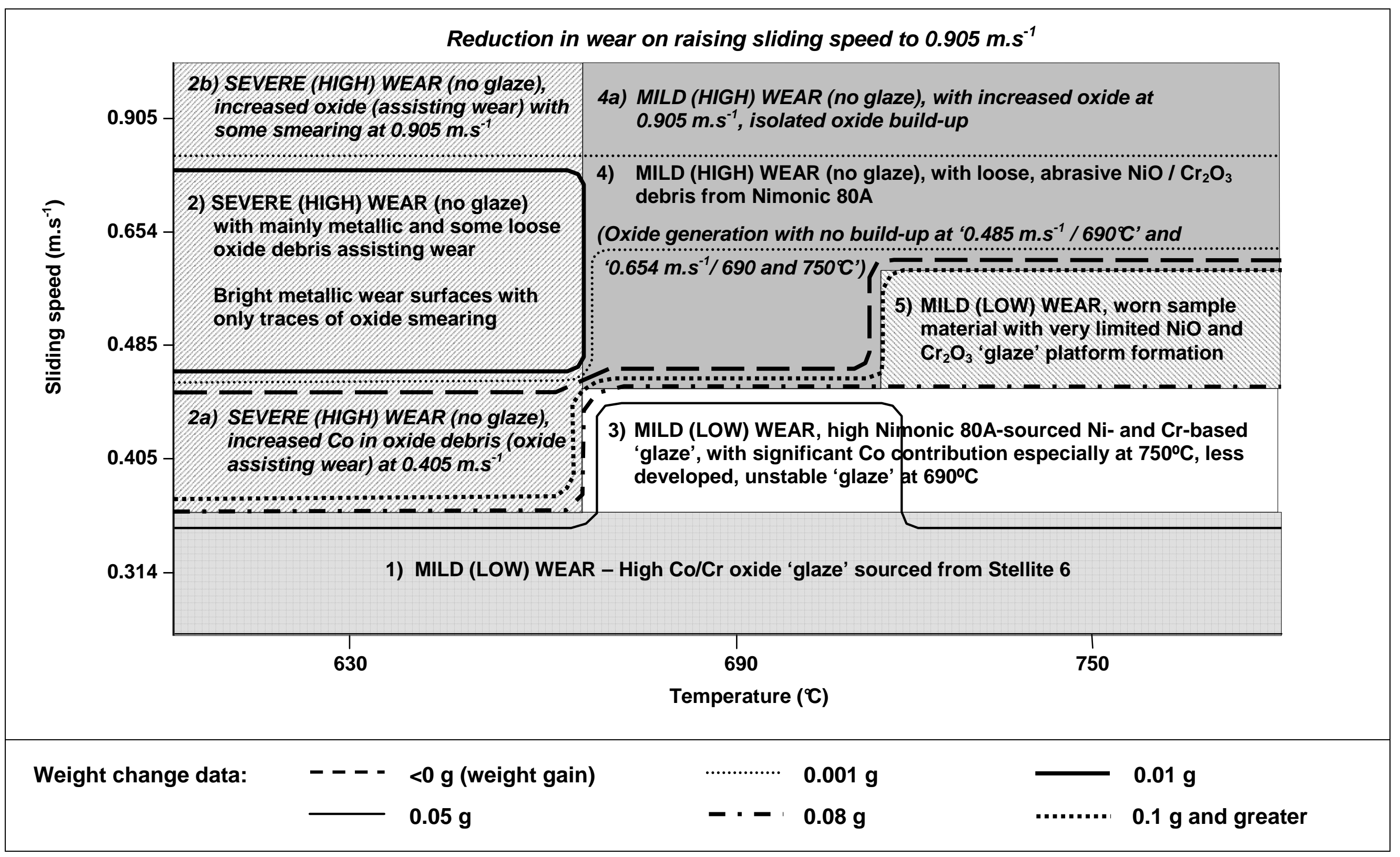

Fig. 14: Wear map for Nimonic $80 \mathrm{~A}$ versus Stellite 6 between $630^{\circ} \mathrm{C}$ and $750^{\circ} \mathrm{C}(\mathrm{load}=7 \mathrm{~N})$, with weight loss (contour) data superimposed; the different areas of shading denote the range of conditions over which the various detailed wear conditions were observed 


\section{Discussion}

Most of the different forms of wear behaviour observed during this study have already been discussed in detail elsewhere [5]. Only the background relevant to the current study and any new findings are discussed (at temperatures of $630^{\circ} \mathrm{C}, 690^{\circ} \mathrm{C}$ and $750^{\circ} \mathrm{C}$ ) following.

\subsection{Sliding at $0.314 \mathrm{~m} . \mathrm{s}^{-1}$}

Analysis of the 'glaze' layers produced at 0.314 m.s ${ }^{-1}$ (region 1, Fig. 14) suggests the lower wear observed occurs predominantly on the Stellite 6 surface. The loose debris initially generated rapidly undergoes agglomeration and sintering to form comprehensive 'glaze' layers on both the Nimonic 80A and Stellite 6 surfaces; once such 'glaze' is formed, the wear substantially decreases. Such 'glazes' are nano-crystalline in nature; their formation and characterisation are detailed elsewhere [1-4].

Although the exact role of the various chemical elements in 'glaze' formation is still uncertain, the fully developed 'glaze' contains high levels of $\mathrm{Co}$ and $\mathrm{Cr}(60 \% \mathrm{Co}, 30 \% \mathrm{Cr}$ at $750^{\circ} \mathrm{C}$ ), due to both $\mathrm{Co}_{3} \mathrm{O}_{4}$ and $\mathrm{CoCr}_{2} \mathrm{O}_{4}$ (as shown by XRD analysis). A primary observation is the initial preferential wear of the harder Stellite 6 compared to the extremely limited wear of the softer Nimonic 80A (as indicated by the Nimonic 80A weight gains in Fig. 3). It is unclear why Stellite 6 undergoes greater wear at low sliding speed, however, one possibility is that early during wear, oxide transferred from the Stellite 6 is embedded in the Nimonic $80 \mathrm{~A}$ surface to create a composite structure. With continued sliding, this composite structure enhances wear and oxide debris generation from the Stellite 6 . Similar behaviour has been observed during wear of some steels by softer copper-based materials [43].

There are two key issues when considering this enhanced Stellite 6 wear at elevated temperatures. Firstly, preferential oxidation of $\mathrm{Co}$ and $\mathrm{Cr}$ is indicated by $\Delta \mathrm{G}$ values in Table 2. Secondly, there is the hexagonal-close-packed to face-centred-cubic phase transition in Stellite 6. Although $\mathrm{Cr}$ increases the transition temperature by $\sim 150^{\circ} \mathrm{C}$ to $\sim 900^{\circ} \mathrm{C}$ [44], ambient and frictional heating, and asperity interaction may during sliding raise interfacial temperature to this level. Also, other alloying elements may lower this phase transition temperature. The formation of a face-centred-cubic phase in Stellite 6, at least at the highest sliding temperatures, will lead to easier (easy dislocation slip) deformation and enhanced material removal. 


\begin{tabular}{|c|c|}
\hline Oxide & $\Delta \mathbf{G}_{727^{\circ} \mathrm{C}}\left(\mathrm{kJJ} \mathrm{mol}^{-1}\right)$ \\
\hline $\mathrm{Co}+1 / 2 \mathrm{O}_{2} \rightleftharpoons \mathrm{CoO}$ & -163.3 \\
\hline $3 \mathrm{Co}+2 \mathrm{O}_{2} \rightleftharpoons \mathrm{Co}_{3} \mathrm{O}_{4}$ & -525.0 \\
\hline $2 \mathrm{Cr}+1 \frac{1 / 2 \mathrm{O}_{2}}{\Rightarrow} \mathrm{Cr}_{2} \mathrm{O}_{3}$ & -861.6 \\
\hline $\mathrm{Ni}+1 / 2 \mathrm{O}_{2} \mathrm{NiO}$ & -150.7 \\
\hline
\end{tabular}

Table 2: Free energies of formation for key oxides $\left(\mathrm{Co}, \mathrm{Cr}\right.$ and $\mathrm{Ni}$ ) at $727^{\circ} \mathrm{C}$ under conditions of static oxidation [44]

The generation of this Stellite 6-sourced oxide debris and subsequent transfer to the Nimonic 80A surface facilitated rapid formation and sustainment of the 'glaze'. The friction data indicated a steady state sliding regime, without any significant jumps to suggest 'glaze-layer' break-up.

\subsection{Sliding at $0.405 \mathrm{~m} . \mathrm{s}^{-1}$ and $0.485 \mathrm{~m} . \mathrm{s}^{-1}$}

Increasing sliding speed causes a shift in preferential wear from the Stellite 6 counterface at $0.314 \mathrm{~m} . \mathrm{s}^{-1}$ to the Nimonic $80 \mathrm{~A}$ sample at $0.485 \mathrm{~m} . \mathrm{s}^{-1}$. This also represents the transition from ready 'glaze' formation to abrasive oxidational wear at $690^{\circ} \mathrm{C}$ and $750^{\circ} \mathrm{C} . \quad 0.405 \mathrm{~m} . \mathrm{s}^{-1}$ represents an intermediate stage, with significant material contribution from both sample and counterface (region 3, Fig. 14) to the 'glaze' layers formed.

At $630^{\circ} \mathrm{C}$, however, the transition at both 0.405 and $0.485 \mathrm{~m} \cdot \mathrm{s}^{-1}$ was to a severe wear, delamination type mechanism (regions 2 and 2a, Fig. 14). The high degree of metallic interaction between the Nimonic $80 \mathrm{~A}$ and Stellite 6 surfaces was accompanied by production of large, flat, predominantly Nimonic 80A-sourced metallic wear debris. However, the greater mechanical action and frictional heating are sufficient to promote oxidation to detectable levels, in the form of smearing on the metallic wear surfaces and limited loose oxide amongst the metallic debris. This loose oxide is sufficient to modify the severe wear behaviour by abrasive action during sliding; effectively the metallic wear surfaces are polished (Fig. 4). Such abrasive action was not observed with lower temperature severe wear $[1,4,5]$ and a good description of this is 'abrasion-assisted-severe-wear'.

This 'abrasion-assisted-severe-wear' is demonstrated in Fig. 15, showing wear surfaces typically obtained at 0.654 and $0.905 \mathrm{~m} . \mathrm{s}^{-1}$ during wear at $510^{\circ} \mathrm{C}$ [5] and $630^{\circ} \mathrm{C}$ respectively; the $630^{\circ} \mathrm{C} / 0.654 \mathrm{~m} . \mathrm{s}^{-1}$ examples are also typical of 0.405 and $0.485 \mathrm{~m} . \mathrm{s}^{-1}$. 
At $0.405 \mathrm{~m} . \mathrm{s}^{-1}$, there is significant material removal from the Stellite 6 (the oxide contains a moderate level of $\sim 11 \% \mathrm{Co}$ ) as well as the Nimonic $80 \mathrm{~A}$ (though wear of the latter is still greater - region 2a, Fig. 14). Increasing the sliding speed to $0.485 \mathrm{~m} . \mathrm{s}^{-1}$ eliminates this Co-contribution as wear of the Nimonic 80A now completely dominates (region 2, Fig. 14), however, this change in debris composition does not modify the $630^{\circ} \mathrm{C}$ 'abrasion-assisted severe wear' behaviour.

A change in wear mechanism occurs at $690^{\circ} \mathrm{C}$, due to increased oxide generation to levels well in excess of debris ejection from the wear interface. Consequently, debris residency is high enough to eliminate metal-to-metal contact, resulting in a technically mild wear regime. Previous studies indicate a low tendency for $\mathrm{NiO}$ and $\mathrm{Cr}_{2} \mathrm{O}_{3}$ debris when present together to sinter and form 'glaze' at high sliding speed, even at elevated temperature $[1,4,5]$. However, at $0.405 \mathrm{~m} \cdot \mathrm{s}^{-1}$ (690 and $\left.750^{\circ} \mathrm{C}\right)$, a combination of:

a) lower sliding speed (compared to 0.654 and $0.905 \mathrm{~m} . \mathrm{s}^{-1}$ in this and previous tests $[1,4,5])$, increasing debris retention and residency, and reducing ejection; and

b) the presence of still significant levels of Stellite 6-sourced Co-containing oxide $(\sim 11 \%$ Co at $690^{\circ} \mathrm{C}$ and $15 \%$ Co at $\sim 750^{\circ} \mathrm{C}$ ), improving oxide sinterability;

promote more favourable conditions 'glaze' formation (region 3, Fig. 14). The protection offered by these 'glaze' layers significantly lowers sample wear (Fig. 3). These layers are, however, less extensive than at $0.314 \mathrm{~m} . \mathrm{s}^{-1}$; at $690^{\circ} \mathrm{C}$ they are also potentially less stable, with highly variable coefficient of friction (Fig. 11) suggesting repeated formation, break-up and reformation of the 'glaze' layers. The presence of fine parallel grooves additionally shows that loose oxide is acting abrasively in 'glaze'-free areas.

The tendency of these 'glaze' layers to form is extremely sensitive to temperature and sliding speed. Even a small sliding speed increase from $0.405 \mathrm{~m} . \mathrm{s}^{-1}$ to $0.485 \mathrm{~m} . \mathrm{s}^{-1}$ is sufficient to:

a) reduce debris residency and retention, and increase mobility; and

b) reduce the contribution of Stellite 6-sourced Co-based material from the counterface (and thus debris sinterability). 
The now completely $\mathrm{NiO}$ and $\mathrm{Cr}_{2} \mathrm{O}_{3}$-dominated debris remains loose and a higher wear, abrasive oxidational regime with little oxide build-up dominates, as evidenced by the dominance of fine parallel grooves lying in the direction of sliding. At $690^{\circ} \mathrm{C}$, 'glaze' formation is completely eliminated (region 4, Fig. 14), with at most the oxide being smeared across the wear scar surface.

The situation is very similar at $750^{\circ} \mathrm{C}$ and $0.485 \mathrm{~m} . \mathrm{s}^{-1}$, with an abrasive oxidational wear regime being promoted by the increased sliding speed. However, increased ambient temperature combined with frictional heating raises the driving force for sintering sufficiently to overcome the reduced debris residency, increased ejection and reduction of Stellite6-sourced Co-based debris to trace levels ( 2.5\%). Traces of fragmented NiO / $\mathrm{Cr}_{2} \mathrm{O}_{3}$-based 'glaze' are thus able to form around the edges of the wear scar (region 5, Fig. 14). A slight reduction in wear compared to that at $690^{\circ} \mathrm{C}$ results (Fig. 3).

The glaze' formation at $750^{\circ} \mathrm{C}$ and $0.485 \mathrm{~m} \cdot \mathrm{s}^{-1}$ from the normally abrasive $\mathrm{NiO} / \mathrm{Cr}_{2} \mathrm{O}_{3}$ debris (with only trace Co-based oxides), has not been previously observed with the 'block-on-cylinder' configuration [1,4,5,8]. This casts uncertainty on the influence of Co-based material at $0.405 \mathrm{~m} . \mathrm{s}^{-1}$ in promoting 'glaze' formation. However, the degree of 'glaze' development at the lower sliding speed does suggest a significant effect. Preliminary studies of Nimonic 80A 'like-on-like' block-on-cylinder sliding at $0.314,0.405$ and $0.485 \mathrm{~m} . \mathrm{s}^{-1}$ (temperature $750^{\circ} \mathrm{C}$ ) also suggest greatly delayed 'glaze' formation (with only abrasive oxidational wear at 0.654 and $0.905 \mathrm{~m} \cdot \mathrm{s}^{-1}$ ), preceded by an extended severe wear period in the absence of Co [45]. Whilst Co clearly promotes 'glaze' formation, the relative influences of Co-content and sliding speed are still unclear and further investigation is required.

\subsection{Sliding at $0.654 \mathrm{~m} . \mathrm{s}^{-1}$ and $0.905 \mathrm{~m} . \mathrm{s}^{-1}$}

At $630^{\circ} \mathrm{C}$, the severe metal-against-metal wear regime observed at 0.405 and $0.485 \mathrm{~m} . \mathrm{s}^{-1}$, continues to dominate at 0.654 and $0.905 \mathrm{~m} . \mathrm{s}^{-1}$ (Fig. 4 shows the wear surfaces; regions 2 and $2 \mathrm{~b}$ on Fig. 14), producing a bright, damaged metallic wear surface and copious quantities of large, flat metallic debris by delamination. Some $\mathrm{NiO}$ and $\mathrm{Cr}_{2} \mathrm{O}_{3}$ debris is also produced, some of which becomes smeared on the metallic wear scars. This oxide is insufficient to prevent metallic contact, but as at lower sliding speed is able to modify severe wear behaviour by abrasion, effectively polishing the metallic wear surfaces and making 
them appear smoother and less torn than at lower temperatures [1,4,5]. This 'abrasion-assisted severe wear' is illustrated in Fig. 15.

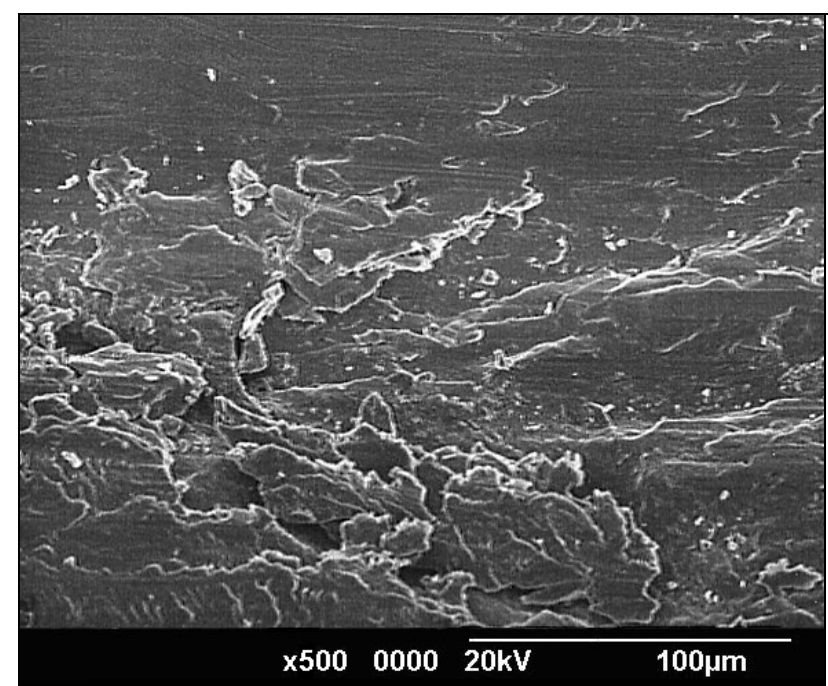

(a) $510{ }^{\circ} \mathrm{C}, 0.654 \mathrm{~m} \cdot \mathrm{s}^{-1}$

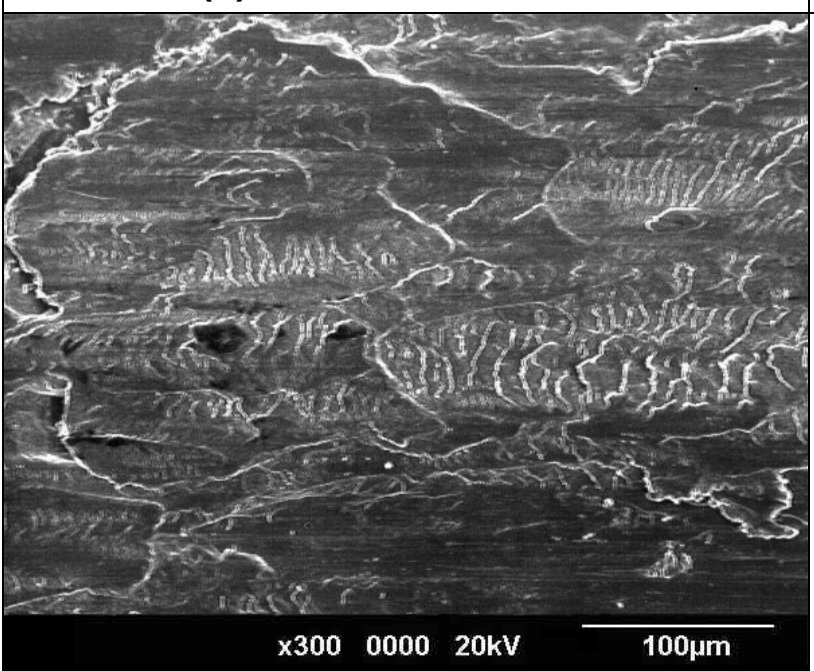

(c) $5100^{\circ} \mathrm{C}, 0.905 \mathrm{~m} . \mathrm{s}^{-1}$

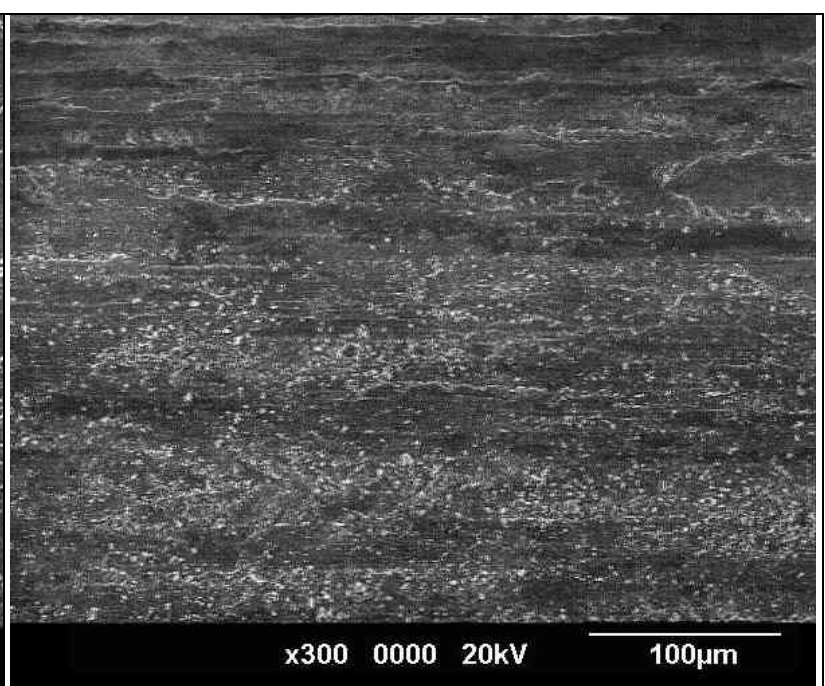

(b) $630^{\circ} \mathrm{C}, 0.654 \mathrm{~m} \cdot \mathrm{s}^{-1}$

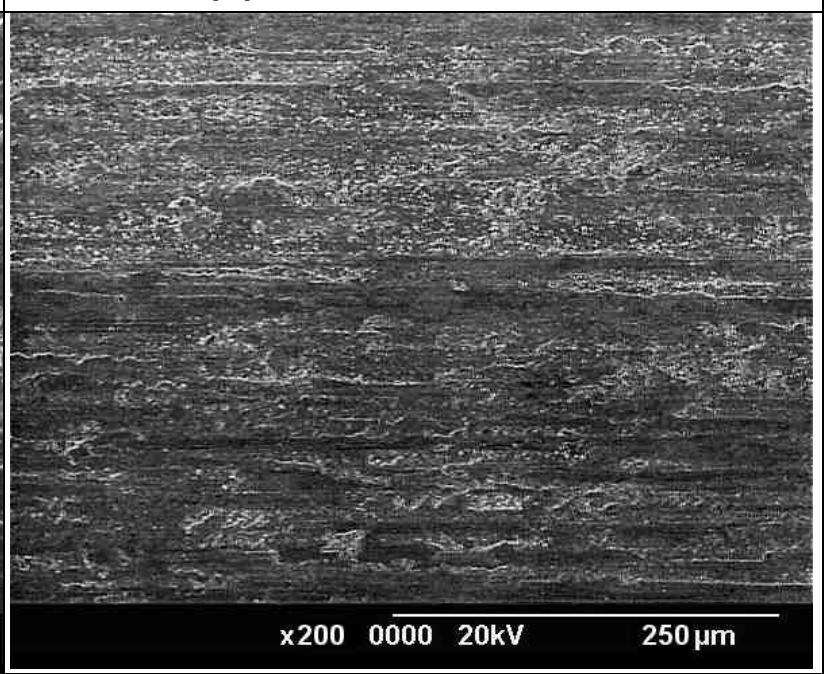

(d) $630^{\circ} \mathrm{C}, 0.905 \mathrm{~m} . \mathrm{s}^{-1}$

Fig. 15: Severe wear produced by sliding of Nimonic 80A versus Stellite 6 at 0.654 and $0.905 \mathrm{~m} . \mathrm{s}^{-1}$, showing torn surfaces produced at $510^{\circ} \mathrm{C}[5]$ and oxide polished surfaces at $630^{\circ} \mathrm{C}$

The greater oxide debris generation at $0.905 \mathrm{~m} . \mathrm{s}^{-1}$ (due to greater mechanical action and frictional heating) compared to $0.654 \mathrm{~m} . \mathrm{s}^{-1}$, whilst still not preventing severe wear, does begin to impede it. Thus lower wear is observed at $0.905 \mathrm{~m} . \mathrm{s}^{-1}$ due to the oxide debris more effectively separating the metallic wear surfaces (region 2b, Fig. 14). Conversely, the lower oxide development at $0.654 \mathrm{~m} . \mathrm{s}^{-1}$ (region 2, Fig. 14) does not have this effect and abrasion dominates. The combination of severe wear and oxide abrasion at $630^{\circ} \mathrm{C}$ and $0.654 \mathrm{~m} \cdot \mathrm{s}^{-1}$ appears to be the most effective for removing material from the Nimonic 80A surface, leading to the highest wear observed during the current study (Fig. 3). 
The increases in $\mathrm{NiO}$ and $\mathrm{Cr}_{2} \mathrm{O}_{3}$ generation at $690^{\circ} \mathrm{C}$ leads to a change to a technically mild wear regime at 0.654 and $0.905 \mathrm{~m}^{-\mathrm{s}^{-1}}$ (regions 4 and 4a; Fig. 14), as happened at 0.405 and $0.485 \mathrm{~m} . \mathrm{s}^{-1}$. Once again, the rate of oxide debris formation was sufficient to exceed the rate of debris ejection from the wear surfaces and the higher debris residency and mobility was enough to eliminate metal-to-metal contact. However, increased ejection and reduced residency allows even less chance for the $\mathrm{NiO}$ and $\mathrm{Cr}_{2} \mathrm{O}_{3}$ debris (now effectively devoid of any Stellite 6-sourced material) to sinter at 0.654 and $0.905 \mathrm{~m} . \mathrm{s}^{-1}$. No 'glaze' thus formed on the Nimonic 80A surface - only a thinly smeared oxide layer (plus isolated build-ups at $0.905 \mathrm{~m} . \mathrm{s}^{-1}$ ) - and these low sinterability oxides instead contributed to wear by abrasion. The abrasive action results in the fine parallel wear groves on the worn Nimonic 80A surface at $690^{\circ} \mathrm{C}$ and $750^{\circ} \mathrm{C}$ (Figs. 5 and 6).

The more pronounced oxide debris generation at 0.905 m.s ${ }^{-1}$ (region $4 \mathrm{a}$; Fig. 14) compared to $0.654 \mathrm{~m} . \mathrm{s}^{-1}$ (690 and $750^{\circ} \mathrm{C}$ ) leading to isolated oxide accumulations on the Nimonic $80 \mathrm{~A}$ surface, are attributable to greater mechanical action and thus frictional heating (i.e. greater thermal driving force). This enhanced oxidation may lead to reductions in observed friction at high sliding speed [42], however, reduced contact between sample and counterface because of high rig vibration at $0.654 \mathrm{~m} . \mathrm{s}^{-1}$ and especially $0.905 \mathrm{~m} \cdot \mathrm{s}^{-1}$ is also likely to contribute to lower apparent friction in the current study. Further work is required to resolve this.

These isolated oxide accumulations do not develop into clear compacted oxide or 'glaze' layers and there is limited effect on wear. The rate of debris removal and breakdown at $0.905 \mathrm{~m} . \mathrm{s}^{-1}$ coupled with the poor sintering characteristics of the $\mathrm{NiO}$ and $\mathrm{Cr}_{2} \mathrm{O}_{3}$ debris, was easily sufficient to overcome oxide accumulation and build-up.

\subsection{Effect of Chemistry and Sliding Speed}

This and previous studies [1,4-6] have shown a variety of behaviour, dependent upon temperature, sliding speed and debris composition generated during sliding (load was not examined during these studies). At $0.314 \mathrm{~m} \cdot \mathrm{s}^{-1}$, it is always wear of the Stellite 6 counterface that is favoured, regardless of whether Nimonic 80A [1, 4, 5] or Incoloy MA 956 is the sample material. A highly sinterable Co-Cr-based oxide is produced that in the study temperature range $\left(630,690\right.$ and $\left.750^{\circ} \mathrm{C}\right)$, readily forms a 'glaze'.

On raising sliding speed to 0.654 or $0.905 \mathrm{~m} . \mathrm{s}^{-1}$, there is a general shift towards preferential sample wear [1, 4-6]. For the Nimonic 80A / Stellite 6 system, this shift results in NiO and 
$\mathrm{Cr}_{2} \mathrm{O}_{3}$ debris generation (Fig. 16), despite $\Delta \mathrm{G}$ values (Table 2) indicating there should be preferential Stellite 6-sourced Co-based oxide production. This debris mostly remained loose and assisted wear by abrasion (at best, there was very limited $\mathrm{NiO} / \mathrm{Cr}_{2} \mathrm{O}_{3}$ 'glaze' formation on the Stellite 6 surface). This abrasion was the sole mode of wear at $690^{\circ} \mathrm{C}$ and $750^{\circ} \mathrm{C}$, whilst at $630^{\circ} \mathrm{C}$, the oxide supported (and modified) metallic severe wear (especially at $0.654 \mathrm{~m} . \mathrm{s}^{-1}$ ). Conversely, the Fe-Cr oxides generated by the Incoloy MA 956 / Stellite 6 system [6] at high sliding speed, formed 'glaze' layers progressively more rapidly and reduced early severe wear as temperatures were raised. At $690^{\circ} \mathrm{C}$ and $750^{\circ} \mathrm{C}$, there was very little evidence of severe wear (Fig. 16).

The change in alloy and thus oxide composition indicates high sliding speed alone is insufficient to inhibit oxide sintering and 'glaze' formation. The Fe-Cr oxides [6] show a much higher degree of sinterability, enabling debris to form 'glaze' even under conditions of high ejection and low residency encountered at $0.905 \mathrm{~m} . \mathrm{s}^{-1}$. The $\mathrm{NiO}$ and $\mathrm{Cr}_{2} \mathrm{O}_{3}$ oxides with poorer sinterability, cannot $[1,4,5]$.

As previously discussed (by swapping sample and counterface for the Nimonic 80A / Stellite 6 system) [1,4,5], the transition from greater wear of Stellite 6 at $0.314 \mathrm{~m} . \mathrm{s}^{-1}$ to greater wear of Nimonic $80 \mathrm{~A}$ at $0.905 \mathrm{~m} . \mathrm{s}^{-1}$ cannot be attributed to the 'block-on-cylinder' geometry. The reasons for the transition are solely due to an increase in sliding speed. Neither can the transition be attributed to an inability of the $\mathrm{Co}-\mathrm{Cr}$ 'glaze' layers generated at $0.314 \mathrm{~m} . \mathrm{s}^{-1}$ to withstand more aggressive conditions at $0.905 \mathrm{~m} . \mathrm{s}^{-1}$. By sliding Stellite 6 versus Stellite 6 at this higher speed, it was shown that Co-Cr 'glaze' layers are still highly wear resistant [6]. It is unclear at this time why there was this transition to preferential sample wear at $0.905 \mathrm{~m} . \mathrm{s}^{-1}$ for both the Nimonic 80A / Stellite 6 [1,4,5] and Incoloy MA956 / Stellite 6 systems [6]; however, the reasons may be related to greater debris ejection rather than transfer from the Stellite 6.

The introduction of two extra sliding speeds $\left(0.405\right.$ and $\left.0.485 \mathrm{~m} . \mathrm{s}^{-1}\right)$ have indicated a more subtle transition between Stellite-sourced $\mathrm{Co}-\mathrm{Cr}$ oxide generation and ready 'glaze' formation, and Nimonic $80 \mathrm{~A}$-sourced $\mathrm{NiO} / \mathrm{Cr}_{2} \mathrm{O}_{3}$ generation and abrasive oxidative wear. It is unclear, however, whether sliding speed or Co levels are the main influence on this, though for example at $0.405 \mathrm{~m} . \mathrm{s}^{-1}$, the presence of Stellite 6-sourced Co-based oxide did appear to more readily encourage 'glaze' formation. 


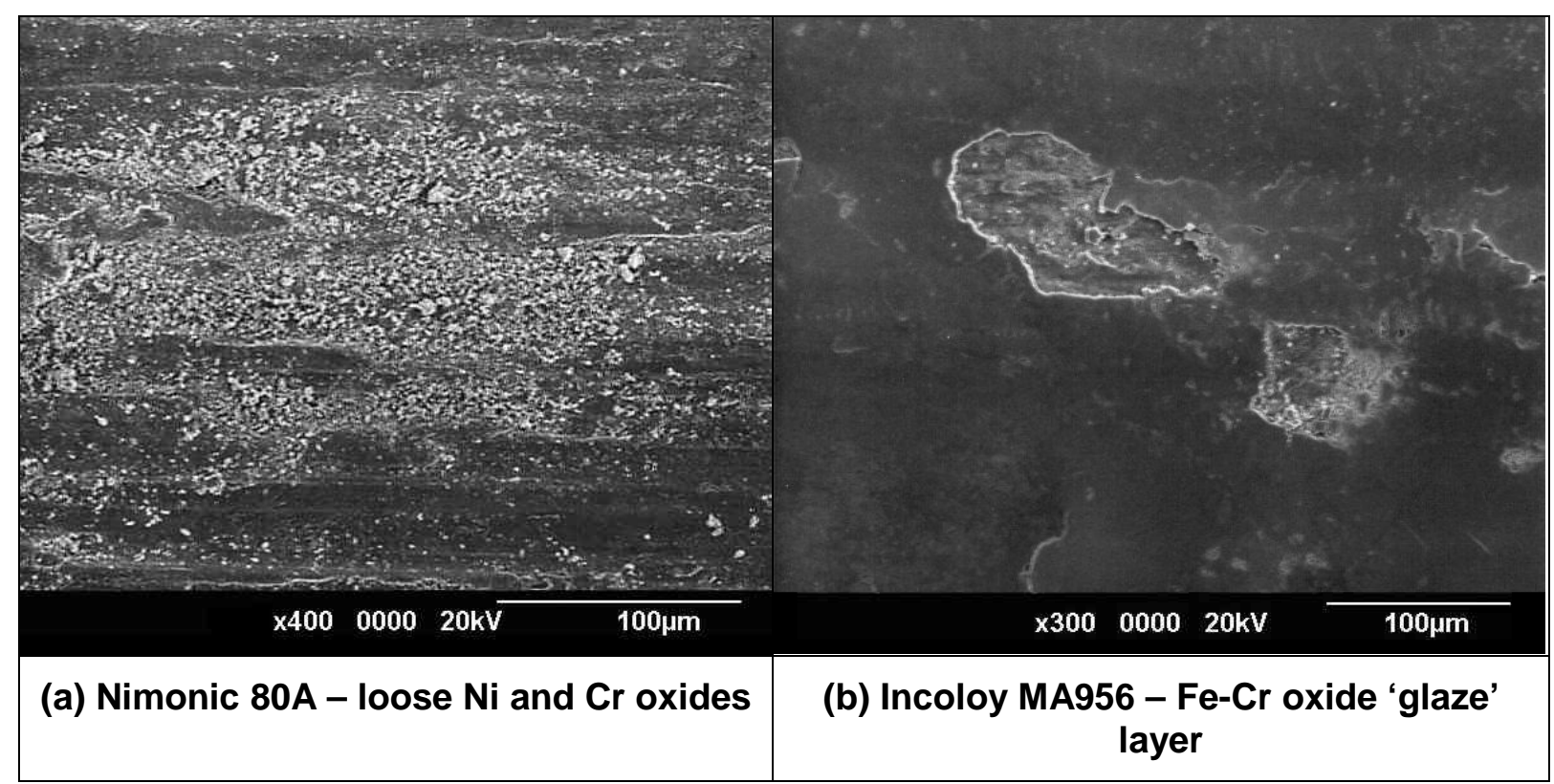

Fig. 16: Oxides on sample sliding surfaces at $0.905 \mathrm{~m} \cdot \mathrm{s}^{-1}$ and $750^{\circ} \mathrm{C}-$ (a) Nimonic $80 \mathrm{~A}$ and also (b) Incoloy MA956 [6] versus Stellite 6

From the data collected during this and previous studies [1, 4-6], it is clear that the tendency of oxides to form 'glaze' depends not just upon sliding conditions, but also their chemical composition (and that of the alloy(s) under wear). For example, it has been seen that:

i) $\mathrm{Co}-\mathrm{Cr}$ based oxides (i.e $\mathrm{CoCr}_{2} \mathrm{O}_{4}$ ) readily form wear protective 'glaze' layers at high temperature and as verified by the Stellite 6 versus Stellite 6 tests [6], at high sliding speed;

ii) $\mathrm{Fe}-\mathrm{Cr}$ oxides can also form fairly robust wear protective layers under adverse, high temperature, high sliding speed conditions [6]; however,

iii) $\mathrm{NiO}$ and $\mathrm{Cr}_{2} \mathrm{O}_{3}$ oxides produced together from Nimonic $80 \mathrm{~A}$ do not too readily sinter together to develop into 'glaze' $[1,4,5]$, but $\mathrm{NiO}$ (produced from Nickel $200^{\mathrm{TM}}$ ) [1] will form a 'glaze' in the absence of $\mathrm{Cr}_{2} \mathrm{O}_{3}$. $\mathrm{NiO}$ mixed with $\mathrm{Cr}_{2} \mathrm{O}_{3}$ only readily forms 'glaze' by reducing sliding speed especially at high temperature, using sliding systems that increase debris retention (for example, using a 'pin-on-disk' system [17, 19-23]; this is discussed in more detail elsewhere [4, 5]) and / or by the addition of other oxides (i.e. Co-based) to encourage 'sintering'.

By engineering the bulk alloy or altering the surface composition (either by coating or alloy additions), oxide chemical composition and sinterability can be controlled, and 'glaze' formation and low wear can be promoted. For example, So et al [27] tested Stellite 6-clad mild steel against two martensitic steels. Various other treatments have been deployed with 
varying success including ion implantation [46], pre-sliding [47] and pre-oxidation [47, 48], however, with the exception of Crook and $\mathrm{Li}$ [49], there has been little attempt to investigate the effect of alloy or oxide composition on the high temperature 'glaze' forming process.

\subsection{Wear Mode Classification}

The different types of wear observed during this and the previous Nimonic 80A versus Stellite 6 wear map studies [5] and illustrated in Figs. 1 (previous study) and 14 (current study), show behaviour that doesn't fit comfortably into Quinn's established 'mild' and 'severe' wear categories [50]. For example, two forms of severe wear have been observed:

1. 'standard severe wear' in the absence of oxide, with adhesion and delamination producing a bright, torn metallic wear surface at higher sliding speed and intermediate temperatures (region 3a on Fig. 1), and

2. 'abrasion-assisted severe wear' (region $3 \mathrm{~b}$ on Fig. 1; also regions 2, $2 \mathrm{a}$ and $2 \mathrm{~b}$ on Fig. 14), with oxide levels too low to prevent metallic contact, adhesion and delamination dominating, but sufficient to assist and enhance wear during sliding by abrasion, producing a smoother, more polished metallic wear surface.

Similarly, two different forms of mild wear behaviour have been observed during these studies:

1. 'protective mild wear' with either (a) loose oxide at low temperature (region 1 on Fig. 1) or (b) 'glaze' layers at high temperature (regions 1a and 2 on Fig.1; also regions 1, 3 and 5 on Fig. 14) acting as a barrier to metallic contact and reducing wear, and

2. 'abrasive mild wear' (region 4 on Fig. 1; regions 4 and 4 a on Fig. 14) where although metallic contact is prevented, the oxide remains loose (for example, by failing to sinter at higher temperature to produce protective 'glaze' layers) and instead acts abrasively to promote high levels of wear.

Quinn's categorisation of wear as 'mild', 'severe' or having elements of both (as with 'abrasion-assisted severe wear') [50], describes general behaviour, however, sub-dividing these where necessary could better cover actual observations.

Various different forms of behaviour with varying degrees of mild and severe wear have also been observed in other studies $[1,4,6,8,45]$. 


\section{Summary of Results}

At $0.314 \mathrm{~m} \cdot \mathrm{s}^{-1}$ :

- Mild wear dominated at 630,690 and $750^{\circ} \mathrm{C}$, with the oxide rapidly sintering to form comprehensive 'glaze' layers. The primary debris source was Stellite 6.

At $0.405 \mathrm{~m} \cdot \mathrm{s}^{-1}$ :

- Severe wear dominated at $630^{\circ} \mathrm{C}$ due to direct metal-to-metal contact between sample and counterface. This was accompanied by limited amounts of $\mathrm{Ni}$ and $\mathrm{Cr}$ oxides, which did not impede wear and in fact assisted it by abrasion (i.e 'abrasion-assisted severe wear').

- Mild wear dominated at 690 and $750^{\circ} \mathrm{C}$ with oxide sintering to form 'glaze' layers. These were less comprehensive than at $0.314 \mathrm{~m} . \mathrm{s}^{-1}$ and were dominated by $\mathrm{Ni}$ - and Cr-based oxides. Sintering properties were improved due to a combination of limited Stellite 6-sourced Co-Cr oxide debris and also still high debris residency at $0.405 \mathrm{~m} . \mathrm{s}^{-1}$, combining to allow 'glaze' to form and protect the Nimonic 80A. In areas where 'glaze' was absent, loose oxide acted as an abrasive agent.

At $0.485 \mathrm{~m} . \mathrm{s}^{-1}$ :

- An 'abrasion-assisted severe wear' regime with some oxide was observed at $630^{\circ} \mathrm{C}$, near identical to that at $0.405 \mathrm{~m} . \mathrm{s}^{-1}$. The higher sliding speed, however, further enhanced wear.

- A mild wear regime was evident at $690^{\circ} \mathrm{C}$. Although technically mild wear, Nimonic 80A wear levels remained high due to abrasion by large amounts of Nimonic 80A-sourced $\mathrm{Ni}$ and $\mathrm{Cr}$ oxides. Due to higher ejection, lower residency and poor sintering characteristics, the oxides did not form compacted or 'glaze' layers on the Nimonic 80A surface. A limited patchy high Ni-Cr oxide 'glaze' layer was present only on the Stellite 6 counterface.

- However, at $750^{\circ} \mathrm{C}$, a combination of higher thermal driving force and still high enough debris residency (ejection was not too severe at $0.485 \mathrm{~m} . \mathrm{s}^{-1}$ ) allowed the formation of limited, unstable Nimonic 80A-sourced $\mathrm{Ni}$ - and Cr-based oxide 'glaze' layers around the edges of the sample wear scar. This slightly reduced wear, however, abrasive wear remained dominant. 
At $0.654 \mathrm{~m} \cdot \mathrm{s}^{-1}$ :

- An 'abrasion-assisted severe wear' regime with some oxide was observed at $630^{\circ} \mathrm{C}$, very similar to that at 0.405 and $0.485 \mathrm{~m} . \mathrm{s}^{-1}$. The increased sliding speed enhanced wear to the highest levels seen during the current study.

- An 'abrasive' mild wear regime was evident at $690^{\circ} \mathrm{C}$ and $750^{\circ} \mathrm{C}$, near identical to that at $0.485 \mathrm{~m} . \mathrm{s}^{-1}$ and $690^{\circ} \mathrm{C}$. Increased sliding speed enhanced the abrasive wear of the $\mathrm{Ni}$ - and $\mathrm{Cr}$-oxides, with no evidence of oxide build-up.

At $0.905 \mathrm{~m} \cdot \mathrm{s}^{-1}$ :

- the wear regimes observed were almost identical to those observed at $0.654 \mathrm{~m} . \mathrm{s}^{-1}$. However, thermally enhanced Ni- and Cr-based oxide production was sufficient to:

i. reduced metal-to-metal contact during severe wear at $630^{\circ} \mathrm{C}$; and

ii. more effectively separate sample and counterface surfaces at $690^{\circ} \mathrm{C}$ and $750^{\circ} \mathrm{C}$;

...in both cases helping to decrease wear. Greater oxide availability allowed for isolated oxide accumulations at 690 and $750^{\circ} \mathrm{C}$, however, these failed to develop into comprehensive compacted oxide or 'glaze' layers and the abrasive mild wear regime remained dominant. Once again, a rough, patchy $\mathrm{Ni}$ - and $\mathrm{Cr}$-based oxide 'glaze' layer was only observed on the Stellite 6 counterface.

The data collected enabled the construction of the simple 'temperature versus sliding speed' wear map presented in Fig. 11.

The ability of a wear generated oxide to form 'glaze' layers depends upon chemical composition as well as sliding conditions (i.e. sliding speed, temperature, etc.). Even minor changes in oxide chemical composition (as well as sliding parameters) can alter sinterability and thus tendency to form glaze. Also, it is suggested that sub-categorising the 'mild' and 'severe' wear modes would better describe the wear behaviour observed. 


\section{Acknowledgements}

Grateful acknowledgements are made to the UK Engineering Physics Science Research Council (EPSRC) and British Gas for their financial backing, and also to Northumbria University for their day-to-day support of this project.

\section{References}

[1] I.A. Inman, Ph.D. Thesis "Compacted Oxide Layer Formation under Conditions of Limited Debris Retention at the Wear Interface during High Temperature Sliding Wear of Superalloys”, Northumbria University, UK (2003), published by ‘Dissertation.com’ (2006).

[2] I.A. Inman, S. Datta, H.L. Du, J.S. Burnell-Gray, S. Pierzgalski, Q. Luo "Microscopy of 'glazed' layers formed during high temperature sliding wear at $750^{\circ} \mathrm{C}$ ", Wear 254 (2003) 461-467.

[3] S. Datta, I. Inman, H.L. Du, Q. Luo "Microscopy of 'glazed' layers formed during high temperature wear, Invited Talk at the Institute of Materials", Tribology Meeting, London, November 2001.

[4] I.A. Inman, S. Datta, H.L. Du, J.S. Burnell-Gray, S. Pierzgalski and Q. Luo "Studies of High Temperature Sliding Wear of Metallic Dissimilar Interfaces", Tribology International 38 (2005) 812-823.

[5] I.A. Inman, S.R. Rose, P.K. Datta "Development of a Simple 'Temperature versus Sliding Speed' Wear Map for the Sliding Wear Behaviour of Dissimilar Metallic Interfaces", Wear 260 (2006) 919-932.

[6] I.A. Inman, S.R. Rose, P.K. Datta "Studies of High Temperature Sliding Wear of Metallic Dissimilar Interfaces II: Incoloy MA956 versus Stellite 6", Tribology International 39 (2006) 1361-1375.

[7] P.D. Wood, Ph.D. Thesis "The Effect of the Counterface on the Wear Resistance of Certain Alloys at Room Temperature and $750^{\circ} \mathrm{C} "$, Northumbria University, UK (1997).

[8] S.R. Rose, Ph.D. Thesis "Studies of the High Temperature Tribological Behaviour of Some Superalloys", Northumbria University, UK (2000).

[9] F.H. Stott, D.S. Lin, G.C. Wood "The structure and mechanism of formation of the "glaze" oxide layers produced on Ni-based alloys during wear at high temperatures", Corrosion Science 13 (1973) 449 - 469.

[10] M. Johnson, P. Moorhouse, J.R. Nicholls, DTI Industry Valve Project, 61-68 (1990).

[11] J-N. Aoh, J-C. Chen "On the wear characteristics of Co-based hardfacing layer after thermal fatigue and oxidation", Wear 250-251 (2001) 611.

[12] Singh, J. and Alpas, A.T. "High-temperature Wear and Deformation Processes in Metal Matrix Composites," Metallurgical and Materials Transactions A, 27 (1996) 3135-3148.

[13] F.H. Stott, J. Glascott, G.C. Wood "Factors affecting the progressive development of wear-protective oxides on iron-base alloys during sliding at elevated temperatures", Wear 97 (1984) 93-106.

[14] M.G. Gee, N.M. Jennett "High resolution characterisation of tribochemical films on alumina”, Wear 193 (1995) 133-145. 
[15] P.D. Wood, P.K. Datta, J.S. Burnell-Gray, N. Wood "Investigation into the high temperature wear properties of alloys contacting against different counterfaces, Materials Science Forum", 251-254 (1997) 467-474.

[16] Wisbey, C.M. Ward-Close, Materials Science and Technology "Wear resistant surfaces on high temperature titanium alloy and titanium aluminide by diffusion bonding", 13 (1997) 349-355.

[17] J. Jiang, F.H. Stott, M.M. Stack, "The effect of partial pressure of oxygen on the tribological behaviour of a Ni-based alloy, N80A, at elevated temperatures", Wear 203-204 (1997) 615-625.

[18] X.Y. Li, K.N. Tandon "Microstructural characterization of mechanically mixed layer and wear debris in sliding wear of an Al alloy and an Al based composite", Wear 245 (2000) $148-161$.

[19] J. Jiang, F. H. Stott, M. M. Stack "A generic model for dry sliding wear of metals at elevated temperatures" Wear 256 (2004) 973-985.

[20] J. Jiang, F. H. Stott, M. M. Stack "The role of triboparticulates in dry sliding wear" Trib. Int. 31-5 (1998) 245-256.

[21] J. Jiang, F. H. Stott, M. M. Stack "Characterization of wear scar surfaces using combined three-dimensional topographic analysis and contact resistance measurements" Trib. Int. 30-7 (1997) 517-526.

[22] J. Jiang, F. H. Stott, M. M. Stack "A mathematical model for sliding wear of metals at elevated temperatures" Wear 181-183 (1995) 20-31.

[23] J. Jiang, F. H. Stott, M. M. Stack "Some frictional features associated with the sliding wear of the Ni-base alloy N80A at temperatures to $250{ }^{\circ} \mathrm{C}$ " Wear 176 (1994) 185-194.

[24] J.K. Lancaster "The Formation of Surface Films at the Transition Between Mild and Severe Metallic Wear", Proc. Royal Society London, A 273 (1962) 466-483.

[25] N.C. Welsh "The Dry Wear of Steels 1, the General Pattern of Behaviour" Phil. Trans., 257A (1965) 31-50.

[26] N.C. Welsh "The Dry Wear of Steels 2, Interpretation and Special Features" Phil. Trans., 257A (1965) 51-70.

[27] H. So "Characteristics of Wear Results Tested by Pin-on-Disc at Moderate to High Speeds", Tribo. Int., Vol. 25, No. 5 (1996) 415-423.

[28] H. So "Wear Behaviours of Laser-Clad Stellite Alloy 6", Wear 192 (1996) 78-84.

[29] C. Subramanium "Wear of Al-12.3 Wt\% Si Alloy Slid Against Various Counterface Materials" Scripta Metallurgica 25 (1991) 1369-1374.

[30] P.J. Blau "Mechanisms for Traditional Friction and Wear Behaviour of Sliding Metals" Wear 72 (1981) 55-66.

[31] S.C. Lim “Recent Development in Wear Maps", Tribo. Int. 31, Nos. 1-3 (1998) 87-97.

[32] S.C. Lim "The relevance of wear-mechanism maps to mild-oxidational wear", Tribo. Int. 35, No. 11 (2002) 717-723.

[33] T.H.C. Childs “The Sliding Wear Mechanisms of Metals, Mainly Steels", Tribo. Int. 13 (1980) 285-293.

[34] A. R. Riahi and A. T. Alpas - "Wear map for grey cast iron" Wear 255 (2003) 401-409. 
[35] H. Chen and A. T. Alpas - "Sliding wear map for the magnesium alloy Mg-9Al-0.9 Zn (AZ91)" Wear 246 (2000) 106-116.

[36] S.H. Yang, H. Kong, E-S. Yoon and D.E. Kim - "A wear map of bearing steel lubricated by silver films" Wear 255 (2003) 883-892.

[37] D. Grimanelisa and T.S. Eyre "Wear characteristics of a diffusion bonded sintered steel with short term surface treatments" Wear 262 (2007) 93-103.

[38] D. Grimanelisa and T.S. Eyre - "Sliding wear mapping of an ion nitrocarburized low alloy sintered steel" Surf. \& Coat. Tech. 201-6 (2006) 3260-3268.

[39] K. Elleucha, R. Elleucha, R. Mnifa, V. Fridricib and P. Kapsab - "Sliding wear transition for the CW614 brass alloy" Tribo. Int. 39-4 (2006) 290-296.

[40] K. Kato and K. Hokkirigawa "Abrasive Wear Diagram”, Proc. Eurotrib '85, Vol. 4, Section 5.3, Elsevier, Amsterdam (1985) 1-5.

[41] K. Adachi, K. Kato and N. Chen "Wear map of ceramics" Wear 203-204 (1997) 291-301.

[42] P.W. Wood, Private Correspondence.

[43] W Czupryk "Frictional Transfer of Iron in Oxidative Wear Conditions during Lubricated Sliding", Wear 237 (2000) 288-294.

[44] E.A. Brandes and G.B. Brook "Smithells Metals Reference Book: Seventh Edition", Butterworth Heinemann (1992).

[45] I.A. Inman "High Temperature 'Like-on-like' Sliding of Nimonic 80A under Conditions of Limited Debris Retention" Unpublished Work, Northumbria University (2003), available on request.

[46] K. Langgath, A. Kluge and H. Ryssel "Wear of Steels After Implantation of Oxygen Ions Or Oxidation at 670K”, Wear 155 (1992) 343-351.

[47] A. Iwabuchi, K. Hori, and H. Kudo "The Effect of Temperature, Preoxidation and Presliding on the Transition from Severe Wear to Mild Wear for S45C Carbon Steel and SUS 304 Stainless Steel” Proc. Int. Conf. Wear of Materials, New York (1987) 211-220.

[48] F.H. Stott and D.R.G. Mitchell "The Influence of Coating on Wear at Elevated Temperatures" Surface Engineering, Volume 1 Fundamentals of Coatings, Ed. P.K. Datta and J.S. Gray (1993) 141-150.

[49] P. Crook and C.C. Li "The Elevated Temperature Metal-to-Metal Wear Behaviour of Selected Hard Facing Alloys" Wear of Materials, ASME Publication 110254, (1983) 272-279.

[50] T.F.J. Quinn "Review of Oxidational Wear. Part 1: The Origins of Oxidational Wear" Tribo. Int., 16 (1983) 257-270.

\section{Errata}

Table 1 (Page 4): In the title, 'Nominal compositions of alloys (at\%)' should read 'Nominal compositions of alloys (wt\%)'. 